\title{
The Music Governors Create and Inspire
}

There is no music so sweet to the American ear as the music of politics. ${ }^{i}$

Robert Taylor, Governor of Tennessee

1887-1891, 1897-1899

\section{John Weingart}

November 2013

January 2014 Addition

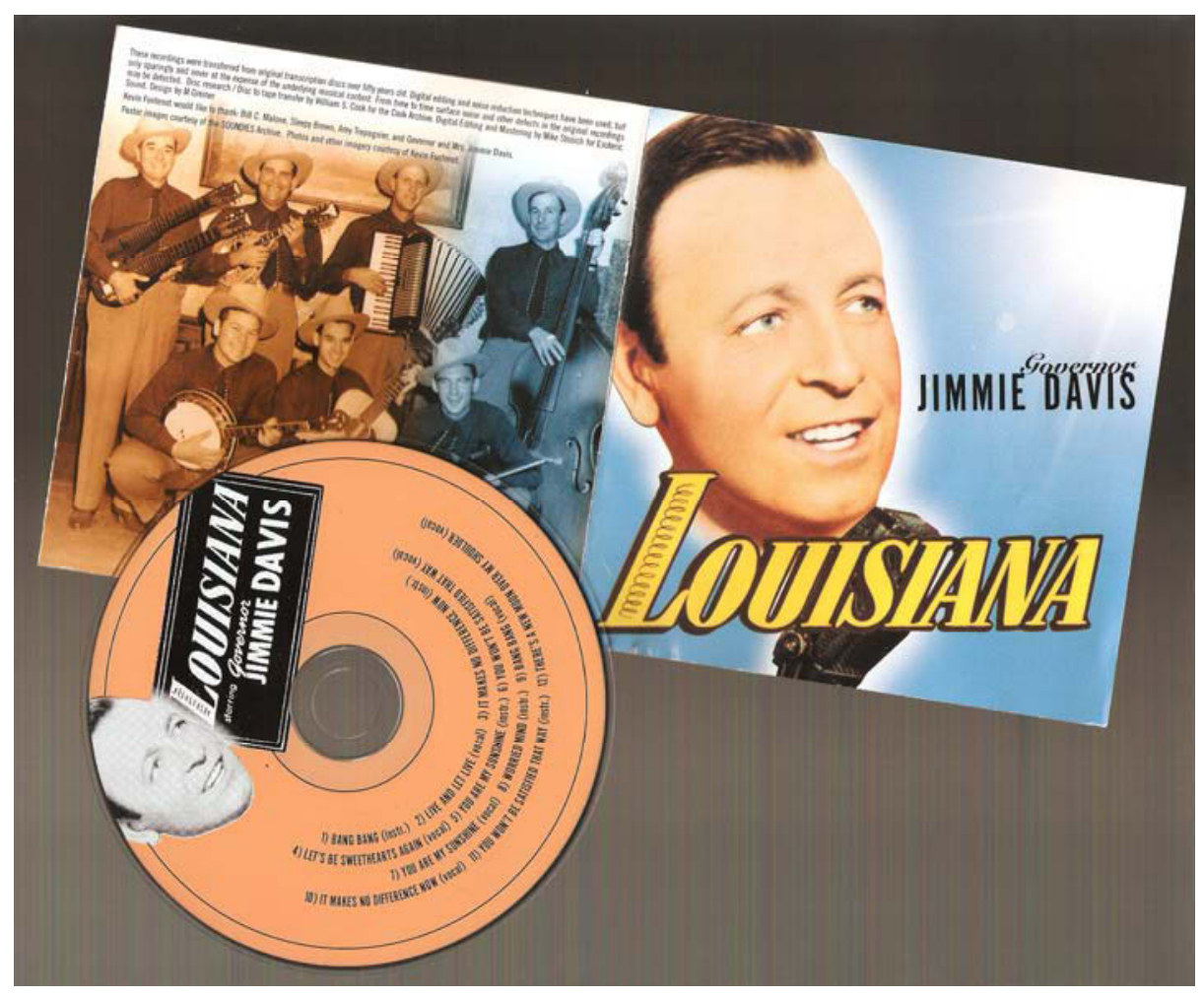

John Weingart is Associate Director of the Eagleton Institute of Politics at Rutgers University and directs the Center on the American Governor. He is also the host of Music You Can't Hear On The Radio, a weekly radio program on WPRB-FM and WPRB.com. This paper has grown from his lifelong affection for American electoral politics and American folk music and bluegrass.

The Center on the American Governor

welcomes additions and corrections

governors@eagleton.rutgers.edu 
Introduction

\begin{tabular}{|c|c|c|c|}
\hline The Music of Governors & State & Governorshp & \\
\hline Sam Houston & Tennessee & 1827-1829 \& Texas: $1859-1861$ & ....... 4 \\
\hline Robert Taylor* & Tennessee & $1887-1891 \& 1897-1899$ & ....... 4 \\
\hline William Spry & Utah & $1909-1917$ & ....... 5 \\
\hline Alfred Taylor* & Tennessee & $1921-1923$ & ....... 5 \\
\hline Al Smith & New York & 1923-1929 & ...... 6 \\
\hline Pat Neff & Texas & 1925 & ....... 7 \\
\hline Huey Long & Louisiana & $1928-1932$ & ....... 8 \\
\hline O.K. Allen & Louisiana & 1932-1936 & ....... 9 \\
\hline Harold G. Hoffman & New Jersey & $1935-1938$ & ....... 10 \\
\hline Earl Long & Louisiana & 1939-1940, 1948-1952 \& 1956-1960 & ....... 11 \\
\hline W. Lee O’Daniel* & Texas & $1939-1941$ & ....... 12 \\
\hline Ellis Arnall & Georgia & 1943-1947 & ....... 13 \\
\hline Jimmie Davis* & Louisiana & $1944-1948 \& 1960-1964$ & ....... 13 \\
\hline Roy Acuff** & Tennessee & 1948 Candidate & ....... 14 \\
\hline Adlai Stevenson & Illinois & 1949-1953 & ....... 14 \\
\hline Orval Faubus & Arkansas & $1955-1967$ & ....... 15 \\
\hline Bill Scranton & Pennsylvania & $1963-1967$ & ....... 16 \\
\hline Milton J. Shapp* & Pennsylvania & 1971-1979 & ....... 17 \\
\hline Dan Walker & Illinois & $1973-1977$ & ....... 18 \\
\hline Leonard Ray Blanton & Tennessee & 1975-1979 & ....... 19 \\
\hline Bill Clinton* & Arkansas & 1979-1981 \& 1983-1992 & ....... 19 \\
\hline Howard Dean & Vermont & $1991-2003$ & ....... 20 \\
\hline Mike Huckabee* & Arkansas & $1996-2007$ & ....... 21 \\
\hline Jim McGreevey plus 4 & New Jersey & $2002\left(\operatorname{Jan} 8^{\text {th }}-12^{\text {th }}\right)$ & ....... 22 \\
\hline Cornelius "Con" Hogan** & Vermont & 2002 Candidate & ....... 23 \\
\hline Rod Blagojevich & Illinois & 2003-2009 & ........ 23 \\
\hline Jon Huntsman* & Utah & 2005-2009 & ....... 24 \\
\hline Kinky Friedman** & Texas & 2006 Candidate & ....... 24 \\
\hline Martin O’Malley* & Maryland & 2006-Present & ....... 25 \\
\hline Scott Walker & Wisconsin & 2011-Present & ....... 25 \\
\hline
\end{tabular}

Singing Governors, Fiddling Senators; a guide by Burgin Mathews (excerpts)

$\begin{array}{lll}\text { Bob and Alf Taylor } & \text { Tennessee } & \ldots . . . .26 \\ \text { “Pappy” Lee O’Daniel } & \text { Texas } & \ldots . . .27 \\ \text { Governor Jimmie Davis } & \text { Louisiana } & \ldots \ldots . .28\end{array}$

Bibliography and Acknowledgements

Endnotes
Table of Contents 3 3 3 14 14 15 16 17 18 9

\section{.} 23 


\title{
The Music Governors Create and Inspire
}

\author{
There is no music so sweet to the American ear as the music of politics. \\ Robert Taylor, Governor of Tennessee \\ 1887-1891, 1897-1899
}

This paper is a stop at the intersection between music and governors, both songs written about governors as well as music some governors wrote or performed themselves. While the number of known songs and tunes in this mini-genre is too small to provide a basis for grand hypotheses, some offer small windows into discrete chapters of American political history and several reveal the musical abilities of individual politicians.

At all levels, the body of music connected to American electoral politics is not large. Songs about the actions of specific officeholders are rare, and campaign songs written to support particular candidates tend to be forgotten soon after the rally or campaign for which they were composed.

The one campaign song to have endured in popular culture is The MTA Song, which was a national hit single in 1959 and is still widely remembered and sung more than 50 years later. Written to support Walter A. O’Brien, a candidate seeking to become Mayor of Boston, The MTA Song told of a recent subway fare increase O'Brien opposed that was to be collected as passengers exited the train. "Charlie," the hero of the song, lacks the nickel needed to disembark and is, therefore, fated "to ride forever" as "the man who never returned." Unfortunately, for O'Brien, the song's unlikely commercial success came a full decade after his electoral defeat in 1949. To add insult to injury, the group that sang it - The Kingston Trio - opted to change O'Brien's first name from Walter to George so that the rousing last chorus became:

Now you citizens of Boston

Don't you think it's a scandal that the people have to pay and pay

Fight the fare increase, vote for GEORGE O'Brien

Get poor Charlie off the MTA.

Within the small subset of political songs that mention governors, most are about those who sought the White House - their national campaigns, their activities in office and, in the case of former Governors William McKinley from Ohio and Franklin D. Roosevelt from New York, their deaths while serving as President. ${ }^{i i i}$

McKinley's assassination in 1901 sparked a song usually called The White House Blues [View] that has survived as a bluegrass standard. Written soon after the sad event, the song contains the oddly uncompassionate line, "Hush little children, don't you fret; You know you'll draw a pension at your daddy's death." Nevertheless - or perhaps in part as a result - it continues as a frequently sung and recorded ballad. Most groups keep the song focused on McKinley, but one recorded on Election Day in 1976 rewrote it to express very limited expectations for Georgia Governor Jimmy Carter's anticipated rise to the presidency. ${ }^{\text {iv }}$

This paper touches on music related to 26 governors, including 18 whose names found their way into song and 10 who themselves made music. Two - Huey Long of Louisiana and W. Lee O'Daniel of Texas - fall into both categories. Also discussed are three musicians whose gubernatorial candidacies were unsuccessful. 


\section{The Music of Governors}

\section{Sam Houston}

Tennessee

1827-1829

Texas 1859-1861

Sam Houston is the only governor to have held the post in two states. In 2006, former Massachusetts Governor William Weld (1991-1997) made an attempt to follow in his footsteps. As he publicly explored a race for the same job in New York state, Weld told audiences about Houston:

Sam was governor of the state of Tennessee and then the first governor of Texas. When my friend Lamar Alexander from Tennessee [Governor from 1979-1987 and U.S. Senator since 2003] heard about my interest in running for governor here in New York, he gave me a copy of the famous Sam Houston biography, The Raven, and told me, 'You'll like Sam. He's a quitter, just like you.' I told him he was right. I think, like Sam Houston, I've always been a principled quitter. ${ }^{v}$

Another view of Sam Houston comes from a song written by Philip Gibbs. Gibbs came to write it after he had been "studying a lot of Texas History ... particularly about ol' Sam:

I wanted to focus on Sam's lost years - between Tennessee \& Texas. Apparently he was late to marry for a politician. He was Governor of Tennessee and 35 and he was strongly advised to take a wife. He did, and shortly thereafter it all fell apart and he quit his job as Governor like it was a job dishwashing. ${ }^{\text {vi }}$

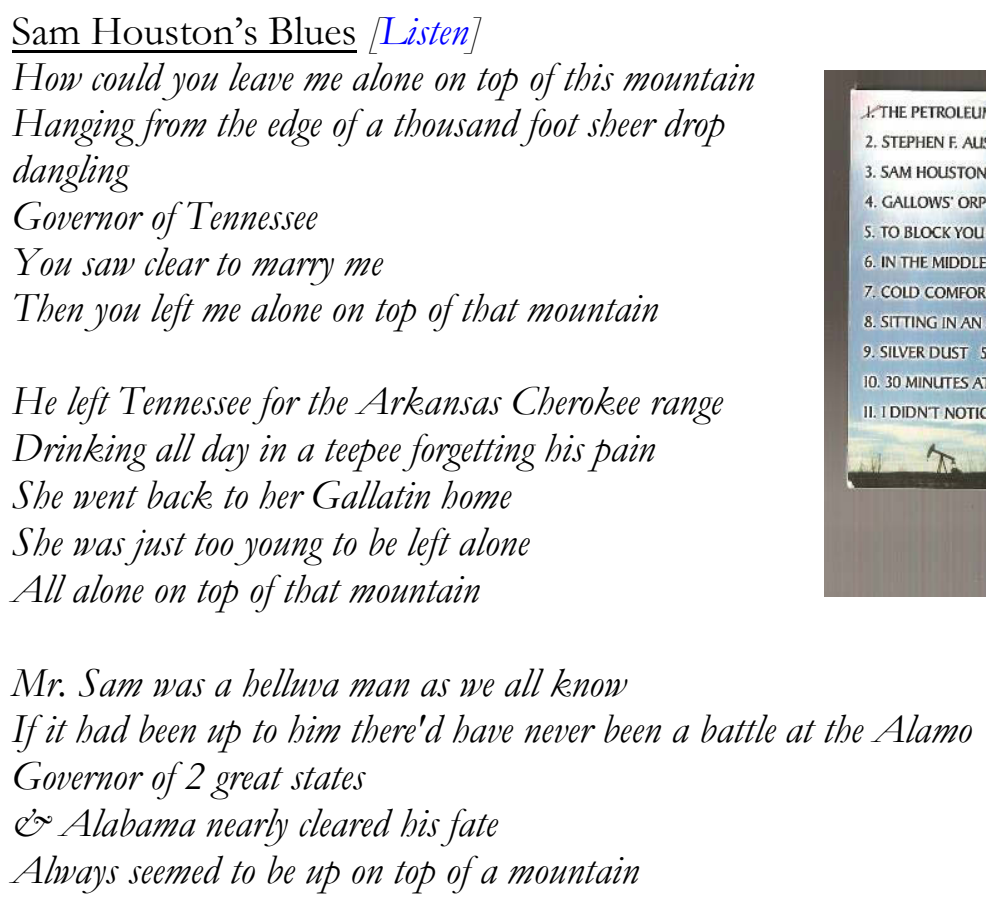

Robert Taylor

Tennessee

1887-1891 \& 1897-1899

Robert Taylor and his brother Alfred were both known in Tennessee for playing the fiddle at country dances, and also for their political careers. Soon after Robert secured the Democratic nomination for Governor of Tennessee in 1886, the Republican Party enlisted brother Alfred to oppose him. During the campaign, according to writer Burgin Mathews in his booklet titled, Singing Governors, Fiddling Senators, "The brothers traveled the state, debating by day, singing and fiddling by night, and often sharing a hotel bed before moving on to their next engagement." In addition to serving twice as governor, Robert is remembered in the name of a fiddle waltz that became known as "Bob Taylor's March."

[Read more about Robert Taylor and his brother Alfred] 


\title{
William Spry \\ Utah \\ 1909-1917
}

A half-century after leaving office, the late Utah Governor William Spry received a shout-out of sorts in a song written by Phil Ochs about union organizer Joe Hill. After Hill had been convicted of murder and sentenced to death, it was Governor Spry, along with the Utah Board of Pardons, who, responding to a request from thenPresident and former New Jersey Governor Woodrow Wilson, temporarily stayed his execution. State officials, however, concluded that no new evidence had emerged and Governor Spry was among those refusing to issue a second delay. On November 19, 1915, Joe Hill was executed by a firing squad. Phil Ochs was a prominent and influential singer-songwriter in the 1960 s with a repertoire largely centered on songs of political and social commentary and advocacy.

\author{
Joe Hill \\ ... Now, William Spry was Governor Spry \\ And a life was his to hold \\ On the last appeal, fell a governor's tear \\ "May the Lord have mercy on your soul... \\ Even President Wilson held up the day \\ But even be would fail \\ For nobody heard the soul searching words \\ Of the soul in the Salt Lake City jail... \\ Now, some say Joe was guilty as charged \\ And some say be wasn't even there \\ And I guess nobody will ever know \\ 'Cause the court records all disappeared'... \\ Say wherever you go in this fair land in every union hall \\ In the dusty dark these words are marked \\ In between all the cracks upon the wall... \\ It's the very last line that Joe Hill wrote \\ When he knew that his days were through \\ "Boys, this is my last and final will \\ Good luck to all of you, good luck to all of you vii
}

\begin{abstract}
Alfred Taylor $\quad$ Tennessee 1921-1923
Alfred Taylor was finally elected governor 35 years after he had lost to his brother. (Robert Taylor had died in 1912.) His name, too, found its way into a fiddle tune when a hunting companion wrote, or at least named, a tune, "Alf Taylor's Fox Chase."

[Read more about Alfred Taylor and his brother Robert]
\end{abstract}




\section{Al Smith \\ New York \\ 1919-21 \& 23-1929}

Al Smith, the four-term Governor of New York, was the Democratic presidential nominee in 1928. While his support for the repeal of prohibition was not sufficient to gain him the White House, it did garner at least two musical endorsements. The one better known comes from Uncle Dave Macon (1870-1952), a popular banjo player and vaudeville entertainer who later became the first star of the Grand Ole Opry:

Governor Al Smith [View]

Al Smith nominated for president, darlin'. Al Smith nominated for president, darlin'. Al Smith nominated for president, My vote to bim I'm a-gonna present, darlin'.

Al Smith is a mighty fine man, darlin'...

He wants to be president of our land, darlin'.

Moonshine's been here long enough, darlin'.

Let's all vote right and get a-rid of this stuff, darlin'...

Another pro-Smith song that explicitly praised his record as a "good governor" came from the Carolina Night Hawks from Ashe County, North Carolina. Recorded in Atlanta on April 17, 1928, the band's banjoist Donald Thompson recalled:

I was hoping our record would help Al Smith, but I don't think it ever got far enough along to help him much. He got defeated. Even so, I think we did a pretty good job on our record. ${ }^{\text {iii }}$

Perhaps it was a bad omen for the Smith campaign when the musicians set their words to the tune of The White House Blues, the song that had told of the assassination of President (1897-1901) and former Ohio Governor (1892-1896) William McKinley:

Governor Al Smith For President

Let's nominate Al Smith, nominate I say,

Then he'll fly through on election day,

Get through all the way!

He made a good governor, you all will agree,

He'll make a good president, as good as can be,

Yes he will, yes be will!

Cal in the White House preparing for his rest

Al and his buddies are doing their best

He's bound to win, bound to win

Hoover in the north land, He's firing his gun

Smith's in Dixie winning every one

Hard to beat, hard to beat 
Pat Neff

Texas

1921-1925

The most - and perhaps - only influential song about a governor was a personal plea written by a prisoner asking that his jail sentence be reduced. The writer was Huddie Ledbetter, who would later gain international renown as the folk singer and major musical influence known as Lead Belly. But in 1924, he was seven years into a 30-year sentence at the Shaw State Prison Farm when Texas Governor Pat Neff came to tour the facility. Ledbetter's guitar playing and singing had received sufficient local attention that he was given the opportunity to perform for the special guest and wrote a song for the occasion that began:

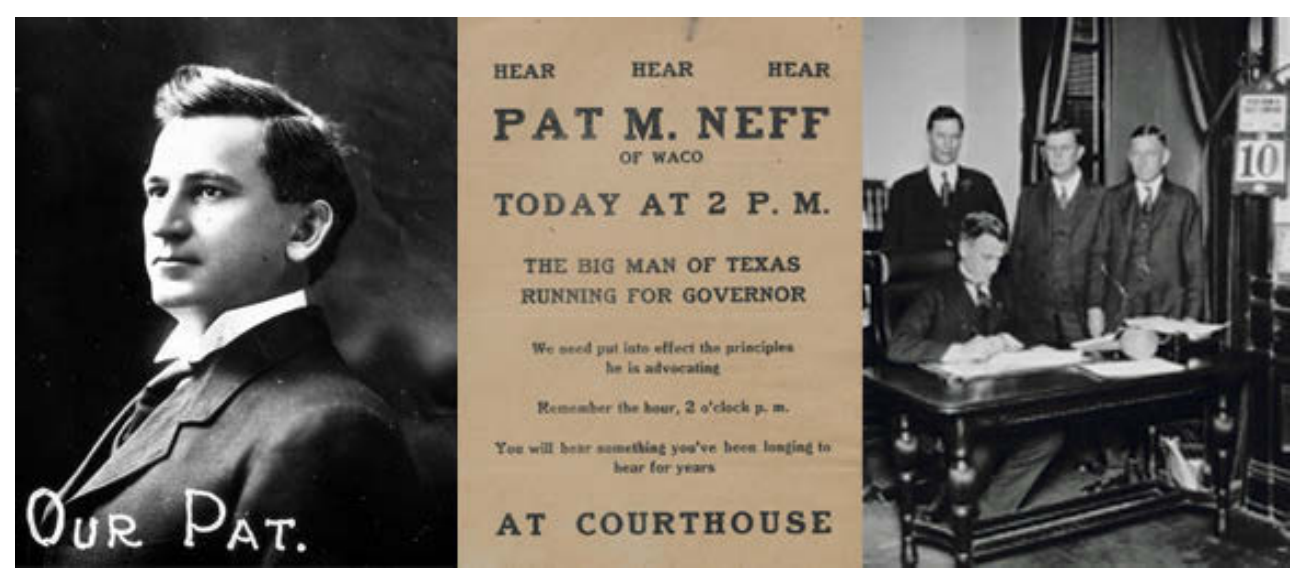

\section{$\underline{\text { Governor Pat Neff }}$}

In nineteen hundred and twenty-three,

When the judge took my liberty away from me

I left my wife wringin' her hands and cryin',

Saying Lord have mercy on that man of mine.'

I told my wife before I left the land, if I never no more see her do the best she can.

If I had Governor Neff like you got me,

I'd a-wake up in the mornin', I would set you free

On January 15, 1925, Governor Neff “commuted nearly 23 years of Ledbetter's sentence for murder, enabling him to walk out of the Huntsville Penitentiary a free man."” 


\section{Huey Long}

\section{Louisiana}

1928-1932

Every Man A King, the popular name for Louisiana Governor Huey Long's platform, became the title for a campaign song co-written by Long and Castro Carazo:

Every Man A King [View]

Why weep or slumber America, Land of brave and true

With castles and clothing and food for all, All belongs to you

Ev'ry man a king, ev'ry man a king, For you can be a millionaire

But there's something belonging to others,

There's enough for all people to share

When it's sunny June and December too, Or in the winter time or spring

There'll be peace without end, Ev'ry neighbor a friend, With ev'ry man a king.

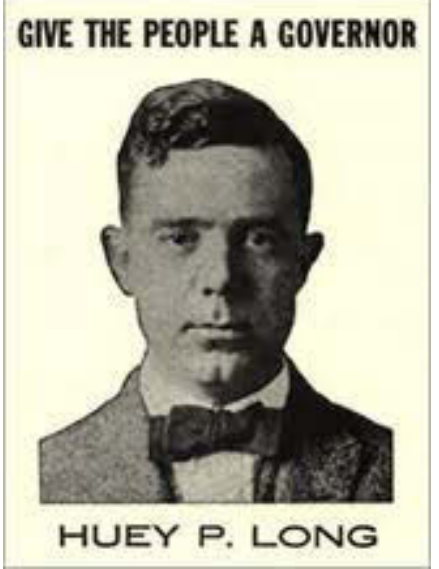

The song gained renewed life in 1974 when it was arranged and recorded by Randy Newman for an album called Good Old Boys. Also on the LP is a song written by Newman about Huey Long: ${ }^{\text {xi }}$

\section{$\underline{\text { Kingfish }}$}

...Who built the bighway to Baton Rouge?

Who put up the hospital and built you schools?

Who looks after shit-kickers like you?

The Kingfish do

Who gave a party at the Roosevelt Hotel?

And invited the whole north balf of the state down there for free

The people in the city

Had their eyes bugging out

Cause every one of you looked just like me

Kingfish, Kingfish, Everybody sing

Kingfish, Kingfish, Every man a king

Who took on the Standard Oil men

And whipped their ass

Just like be promised he'd do?

Ain't no Standard Oil men gonna run this state

Gonna be run by little folks like me and you

Kingfish, Kingfish

Friend of the working man

Kingfish, Kingfish

The Kingfish gonna save this land 


\section{O.K. Allen \\ Louisiana \\ 1932-1936}

Nine years after Huddie Ledbetter was freed in Texas, he was back in jail, but this time in Louisiana.

Writing to this state's governor, Oscar K. (O.K.) Allen, he recycled a line from his song to Governor Neff beginning, as he had in Texas, by establishing the year:

Governor OK Allen [View]

In nineteen bundred and thirty-two

Honorable Governor O.K. Allen, I'm pleading to you

I left my wife wringing her hands and crying,

"Honorable Governor O.K. Allen, save that man of mine."

Like Texas Governor Neff eight years earlier, Governor Allen pardoned Ledbetter soon after hearing a song that mentioned him by name. In this case, however, the release apparently owed more to the lobbying of folklorists Alan and John Lomax, who had "visited the Penitentiary in search of inmates who knew folksongs, blues, ballads, religious material, and worksongs." "xii In fact, the subsequently recorded versions of this song follow the verse above asking that to be released with the ones below expressing gratitude to now be free.

The final verse could be the eventual centerpiece for any forthcoming collection of songs mentioning Lieutenant Governors by name ${ }^{\text {xiii. }}$

When I looked in the paper, then I was surprised

When I saw the number three hundred and twenty-five.

I know my wife's gonna jump and shout

When the train rolls up and I come stepping out.

Honorable Governor O.K. Allen, remember bim the rest of my life.

He studied up a plan to send so many men to their wives.

When you write you a letter, please don't forget

The Lieutenant Governor Honorable Mr. [John B.] Fournet

Had you, Governor O.K. Allen, like you got me

I would wake up in the morning, let you out on reprieve. ${ }^{x i v}$

Immediately upon his release, Ledbetter became John Lomax's chauffeur and was soon being introduced to concert audiences as "Lead Belly." Over the next quarter-century, he would record hundreds of songs and stories and perform on stage and on radio across the country and in Europe. Lead Belly died from ALS on December 6, 1949, just eight months before his song "Goodnight Irene" by the folk singing quartet The Weavers became a hit and the best-selling record in the country. ${ }^{\mathrm{xv}}$ 


\section{Harold G. Hoffman}

New Jersey

Harold G. Hoffman served as Governor of New Jersey for one term and had the distinction being both preceded and followed by the same man, A. Harry Moore (1926-1929, 1932-1935 \& 1938-1941). Hoffman harbored doubts about the guilt of Bruno Hauptmann, who had been convicted of kidnapping the Lindbergh baby; soon after being elected, he secretly visited Hauptmann in prison.

Hoffman's race in 1934 inspired a campaign song called H-O-F-F-M-A-N with words and music by Amos Harker. The original sheet music includes a biography noting that the 38-year old Hoffman is not only "the youngest candidate ever to seek the office of Governor in New Jersey," but that he "is an arch foe of sham and hypocrisy in politics, a forceful, pleasant and dynamic speaker who has been heard in every nook and corner of his state, a keen student of economics and political science, and a tireless worker."

\section{$\underline{\mathrm{H}-\mathrm{O}-\mathrm{F}-\mathrm{F}-\mathrm{M}-\mathrm{A}-\mathrm{N}}$}

You know some-one who is no stranger to you He is famous all over the state.

From north to south, From the east to the west, He's a man that you all know is great.

He's everyone's friend, he will fight to the end, Just to see that you're all treated square.

So let's get behind him and work till we find

That he's perched in the governor's chair.

\section{Chorus}

$H-O-F-F-M-A-N$

Now if you can spell, why, we're here to tell

That's the name of a wonderful man.

H.O. double F spells HOFF

Just dope the rest out if you can.

They sure knew what they were doing

When they named the last syllable "MAN".

Now be has a smile

That makes life worth while

$H e$ 's a bundle of vigor and vim.

From the mountains of Sussex to Sunny Cape May

There are thousands working for him.

He's ready to fight for the things that are right,
[Listen]

(Recording of H-O-F-F-M-M-A-N performed by Bill Bly, with intro and remarks by John Weingart, on 11/4/13 at the Eagleton Institute of Politics.)

Without any bluster or bluff.

He's a regular guy and maybe that's why

Most everyone's yelling for HOFF.

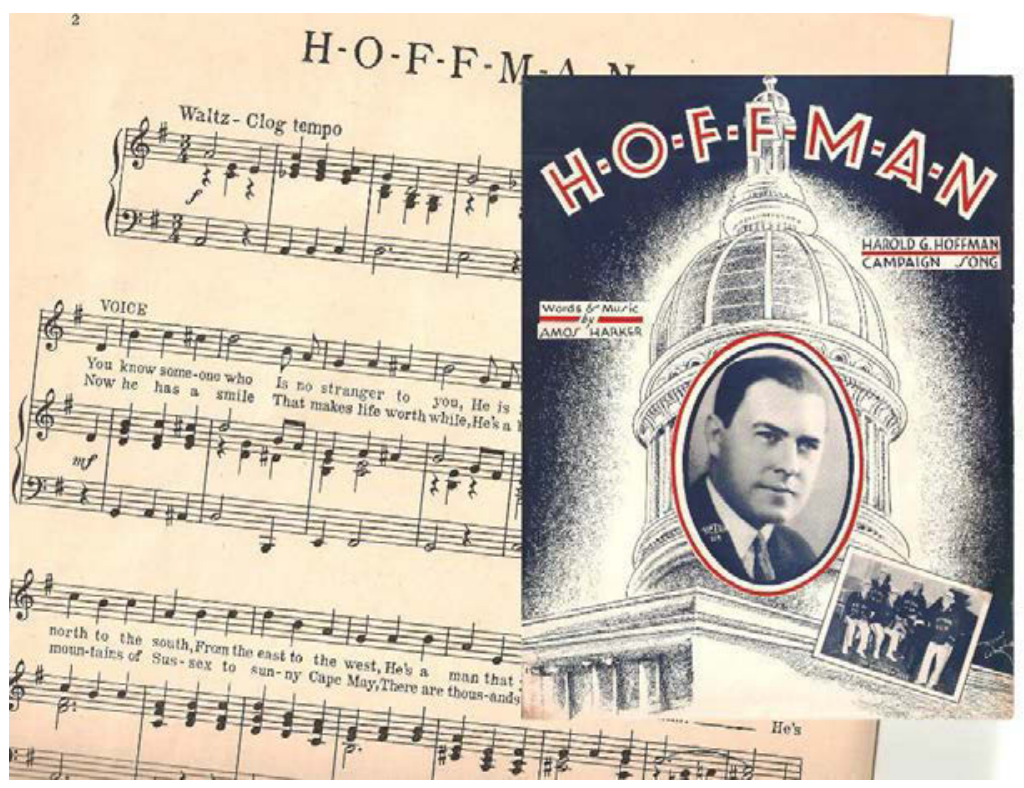


Earl K. Long was Louisiana's $46^{\text {th }}, 49^{\text {th }}$ and $51^{\text {st }}$ Governor. First serving briefly in 1939 and 1940 after the resignation of Governor Richard Leche, he won his own four-year term eight years later. Due to Louisiana's restriction preventing governors from serving more than one consecutive term, Long had to sit out the 1952

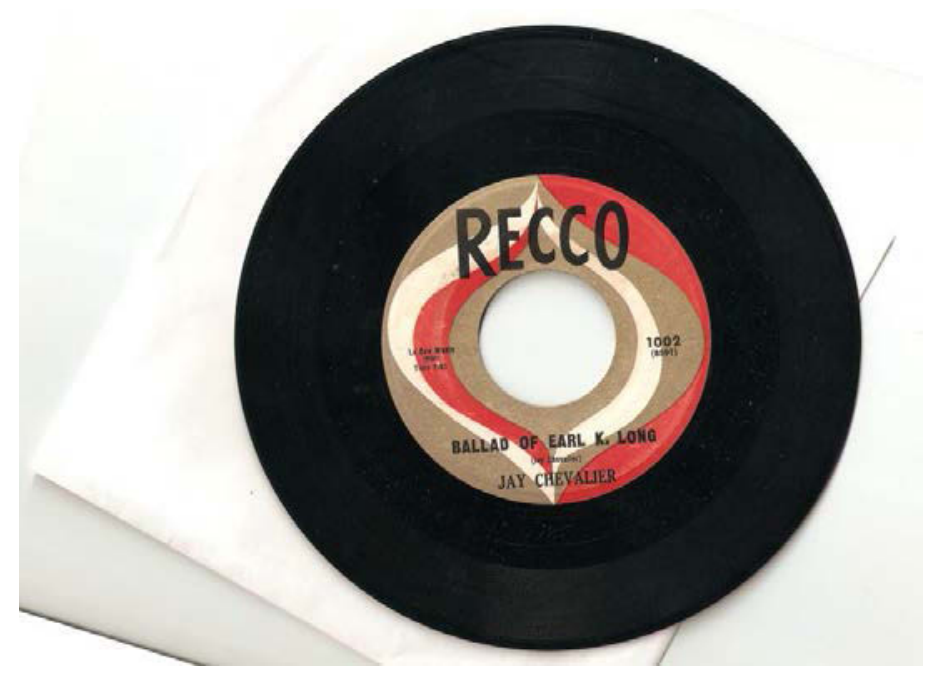
election, but he returned four years later to serve from 1956 to 1960. Alternating with Long for most of those years was the much more musical Jimmie Davis, who served as Louisiana's $48^{\text {th }}$ and $52^{\text {nd }}$ governor.

When he was again unable to seek another term in 1960, Governor Long instead ran for Lieutenant Governor. While the campaign was unsuccessful, it led country and rockabilly singer Jay Chevalier to write and record "The Ballad of Earl K. Long." Released as a single during the campaign, the song became a regional hit.

Thirty-five years later in 1995, Chevalier himself ran for Lieutenant Governor but was defeated by Kathleen Blanco. He was, however, inducted into the Rockabilly Hall of Fame, Louisiana Music Hall of Fame and Louisiana Political Hall of Fame.

After defeating Chevalier, Kathleen Blanco went on to greater fame, serving two terms as Lieutenant Governor and then, in 2003, being elected Louisiana's $54^{\text {th }}$ Governor. The first woman to hold the post in Louisiana, Blanco's term was defined by Hurricane Katrina and its aftermath. Choosing not to seek a second term in 2008, she was succeeded by Bobby Jindal, a candidate she had defeated four years earlier.

Jindal was re-elected in 2012, an event made possible by a 1966 amendment to the Louisiana Constitution allowing governors two consecutive terms.

Governor Earl K. Long [Listen]

Talk about your Jackson, your Robert E. Lee, Sing about Davey from Tennessee

$W$ ay down south in the bayou land, A modern Robin Hood is a-leading his clan

Sing, Sing Louisiana sing, Sing about the Battle of New Orleans

Clap your hands and sing this song, Just a little story of Earl K. Long

Driving around in a black limousine, Everywhere be goes, there's a great big scene

All of the folks come from miles around, Just to see the show when he bits town

Driving around setting the state in a whirl, Saying don't you worry, just trust Uncle Earl...

Some say he's wrong, others not so, The rest of the people just don't know

This one thing they will all agree, Old Uncle Earl is making history ${ }^{\text {xvi }}$ 
W. Lee O'Daniel is the only governor to have been both the subject of song and a musical performer himself. His entry into politics, in fact, was fueled by the prominence he had gained from promoting his Hillbilly Flour Company with a western swing band that played on radio shows and in live appearances throughout the state. Although the band was called W. Lee O'Daniel \& The Light Crust Doughboys, or sometimes W. Lee O'Daniel \& His Hillbilly Boys, O'Daniel neither sang nor played an instrument. Rather, he presided over band performances serving as something of a play-by-play master of ceremonies. He is, however, credited with writing "Beautiful Texas," a song sung and recorded by many performers including Willie Nelson. And in 1940 midway through his term in Austin, The Bar-X Cowboys recorded a song about O'Daniel called The Blue Bonnet Governor.

Decades after his death in 1959, O’Daniel was the basis for the character "Pappy O'Daniel" played by Charles Durning in the Coen Brothers' 2000 film, "O Brother Where Art Thou?" xvii

When O'Daniel was elected Governor of Texas in 1939 in his first race for office, he defeated 12 other candidates.* He was then re-elected in 1940. What is probably more memorable than any accomplishments during his short terms in Austin, however, was his election to the U.S. Senate one year later. O'Daniel's path to Washington began on April 9, 1941 when John Morris Sheppard, who had represented Texas in the Senate since 1913, died in office. Exercising his power as governor, O'Daniel responded by appointing Andrew Jackson Houston to fill the seat. Houston, the son of former Texas and Tennessee Governor Sam Houston, was also at the time of his appointment 86 years old. Two months later, just after turning 87, Houston too passed away. This time, O'Daniel called and entered a special election in which he narrowly defeated then-Congressman Lyndon B. Johnson. It would be the only election Johnson lost.
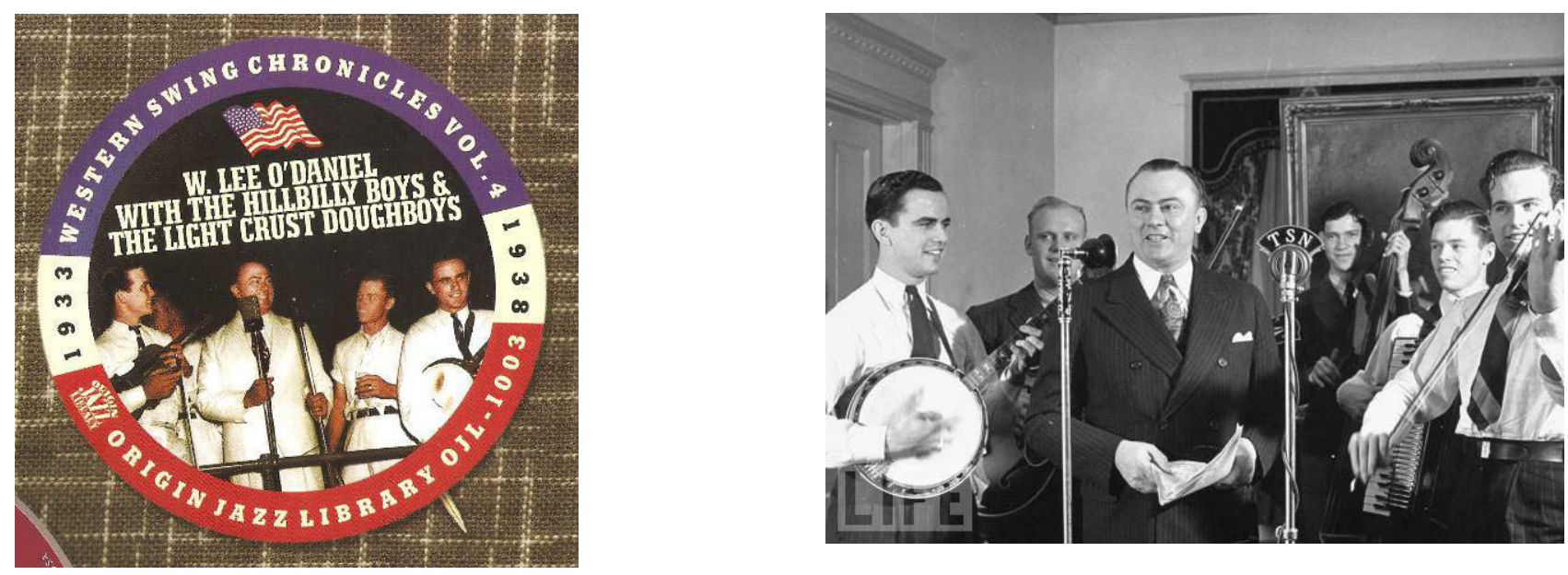

* O'Daniel's victory in 1939 was noted across the country with The Chicago Daily News writing, "Mr. O'Daniel, with his spur-of-the-moment candidacy, his hillbilly band, his radio personality, and his 'turn the politicians out' platform, was just what Texas ordered. A similar, though more pointed, assessment appeared in The Boston Globe: The political swathe cut by Flour Salesman W. Lee O'Daniel and his hillbilly band down in Texas indicates that the lunatic fringe, which appears in month of economic depression, is producing its phenomena of political patent medicine men." (Quoted by Cary Ginell in album notes for W' Lee O’Daniel and his Hillbilly Boys: 1935-38, Texas Rose Records, Sugarland, Texas, 1982.) 
The Blue Bonnet Governor Listen]

The buckeye told the sunflower I think you ought to know

That Governor Lee O'Daniel was born in Obio

You know our sons are famous, history speaks of them

So tell the Texas blue bonnet, Obio's proud of him

He's the blue bonnet governor

The people all love him so

Because he's no professional

Just plain as calico

He works with his Hillbilly Boys

Singing songs to the man with the plow

And the blue bonnets kept their promise

For he's a son of Texas now.

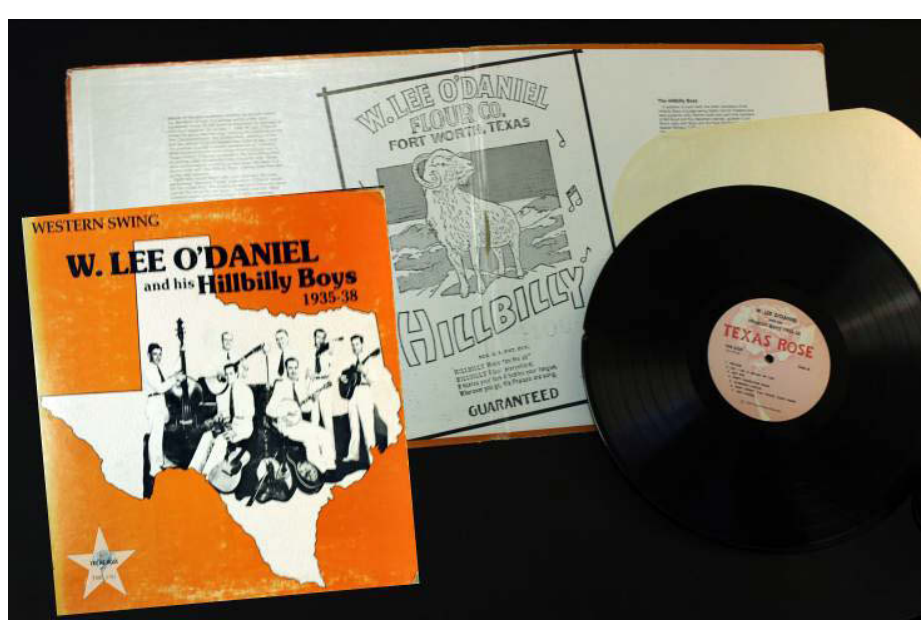

Ellis Arnall

Georgia

1943-1947

I'm Going To Write To The Governor of Georgia by Champion Jack Dupree (1909-1992) was recorded in 1946. Returning to the US after spending two years in a Japanese POW camp, Dupree was dismayed to find racism similar to what he had experienced before the war. In this song, Dupree mentions no specific governor though at that time Georgia's governor was Ellis Arnall. Arnall had been preceded in office by Eugene Talmadge (1933-1937, 1941-1943) and followed by Talmadge's son Herman (1947, 1948-1955). ${ }^{\text {viii }}$

Jimmy Davis

[View1] [View2]

The governor who most successfully blended long careers in both political and music was Jimmie Davis from Louisiana. Davis served two distinct terms as governor, one from 1944-1948 and the other from 1960-1964. His best known and most lasting legacy, however, is probably musical, highlighted by the song "You Are My

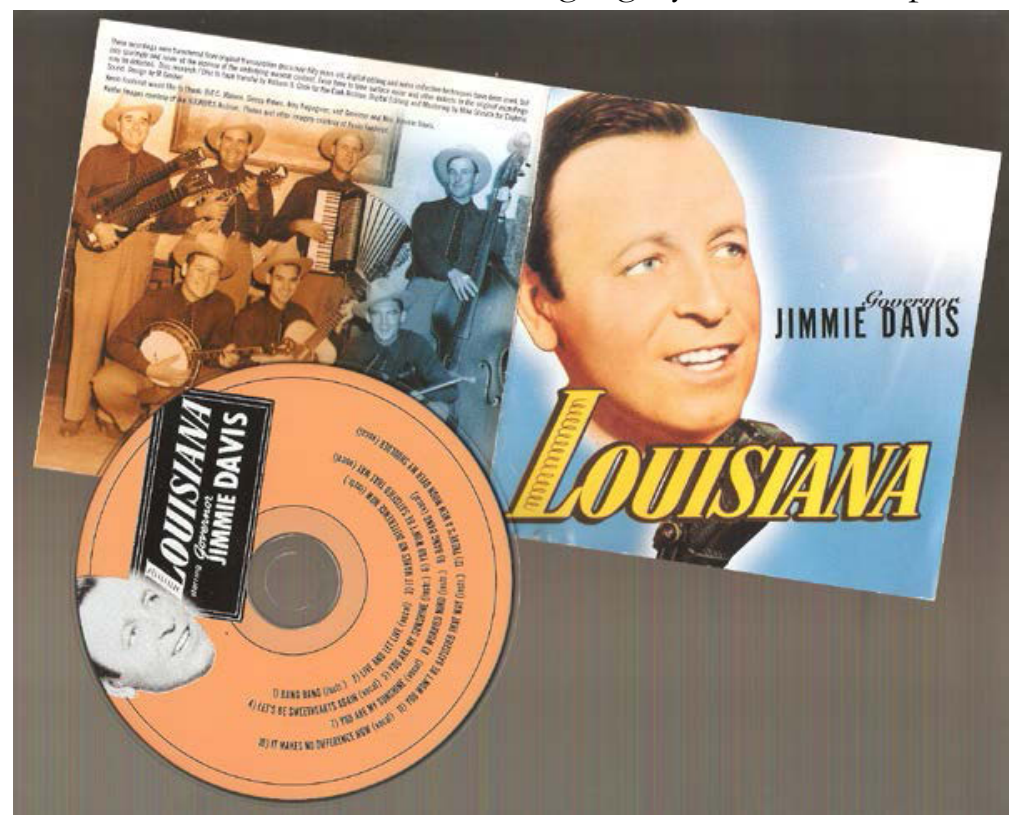

$1944-1948 \& 1960-1964$ Sunshine," which has endured through the decades and, since 1977, been Louisiana's official state song. 
Roy Acuff

Tennessee Candidate

Roy Acuff was a major country music star - sometimes called "The King of Country Music" - from his first appearance on the Grand Ole Opry in 1938 until his death in 1992. In 1948, Acuff was the Republican nominee for Governor of Tennessee but received only $33 \%$ of the vote as he lost to former Governor Gordon Browning.

\section{Adlai Stevenson}

Illinois

1949-1953

While only governor for one term, Adlai Stevenson was the Democratic nominee for President in both 1952 and 1956. Although his defeats by Dwight Eisenhower were by large margins (11\% in 1952 and 14\% in 1956), Stevenson evoked passionate enthusiasm and enduring affection from many of his supporters. Several songs were written about his national campaigns including $W$ e Want Adlai: He Knows The Score; The Man With The Hole In His Shoe; Believe in Stevenson, You Gotta Gotta Win This Time; and We're Madly for Adlai: :ix
1948

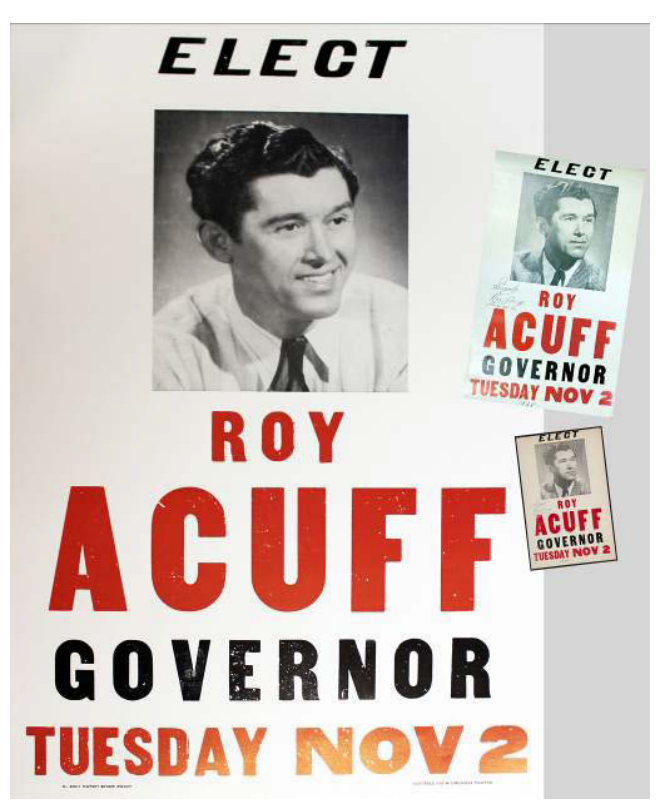

Madly For Adlai LListen
We're madly for Adlai for President
A statesman with experience is he
We're madly for Adlai for President
He has the overall ability
He's courageous, honest, true
In him, we all believe
And with his know-how for the job
He's what the people need
We're with him and for bim
Hip, hip hooray
The White House needs a Mr. Stevenson
We're madly for Adlai for President
So let's send bim down to W ashington 
Orval Faubus

Arkansas

Orval Faubus was Governor of Arkansas for six two-year terms. He gained national attention in 1957 for calling up the National Guard to try to prevent the high school in Little Rock from being integrated. After choosing not to run again in 1966, Faubus was succeeded by Winthrop Rockefeller (1967-1971), whom he had defeated two years earlier. His later attempts to return to the office in 1970, 1974 and 1986 were all rejected by Arkansas voters.

Both of the two known songs about Governor Faubus are critical of his racial policies. One included in a 1962 booklet of songs put together by the Intermountain Folk Music Council in Salt Lake City is introduced as, "a song which expresses the feelings of many people during the Little Rock episode a while back" and set "to the tune of The Jersey Butcher. ${ }^{\mathrm{xx}}$

Governor Faubus
Governor Faubus of Arkansas
Stood up to the government and broke the law;
Stationed troops at a Little Rock school house
When the kids got there, this is what they saw...
That big old tank and the National Guard
Were bein' used as the governor's tool.
Placin' might on the side of white
Just to keep eight kids from a-goin' to school
Federal judge tol' that Arkansas governor
To git his troops away from that school
Mayor of Little Rock, ob he was so right
When he called that governor a damned old fool.
That Arkansas governor is about to start
A civil war all over the south
Puts me in mind of what Lincoln said,
We cannot stand as a divided house.

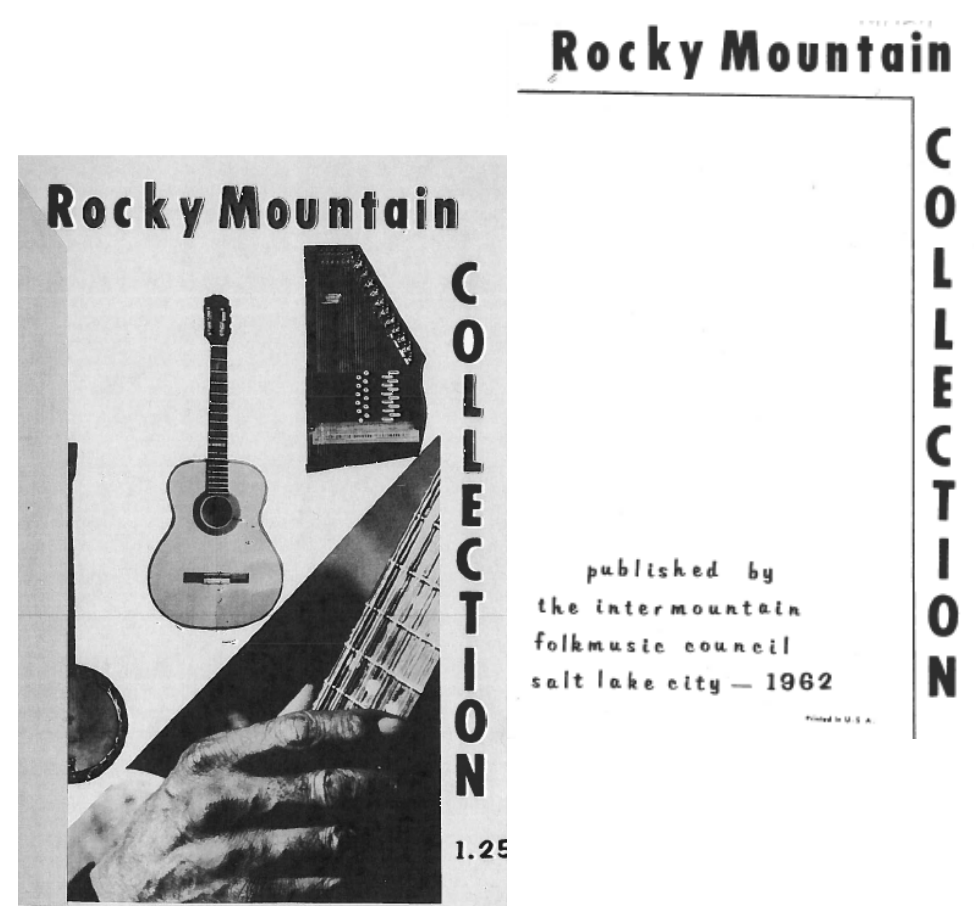

The other, a sly, satirical number titled Fables of Faubus, was written by the great jazz bassist, bandleader and composer Charles Mingus (1922-1979). The journalist Matthew Kassel writes that Mingus, "no stranger to social commentary recorded two well-known versions of this song." Kassel's background on the song continues: "The first was made, instrumentally, on the 1959 album Mingus Ab Um, which contains such enduring compositions as Goodbye Porkpie Hat, which is dedicated to Lester Young, and Better Git It in Your Soul. Mingus had wanted to record the tune with lyrics, but Columbia, his label at the time, refused to let him do it. And so the second recording, which came out in 1960 on the album Charles Mingus Presents Charles Mingus (Candid), and, for contractual reasons, was renamed Original Fables of Faubus, contains words. At the beginning of the track, Mingus says bitingly, "We'd like to continue this set with a composition dedicated to the first, or second or third, all-American heel." ${ }^{\text {xxi }}$ 


\section{Fables of Faubus}

Oh, Lord, don't let 'em shoot us!

Oh, Lord, don't let'em stab us,

Oh, Lord, don't let 'em tar and feather us!

Oh, Lord, no more swastikas!

Ob, Lord, no more Ku Klux Klan!

Name me someone who's ridiculous, Dannie

Governor Faubus!

Why is he so sick and ridiculous?

He won't permit integrated schools...

Two, four, six, eight:

They brainwash and teach you hate.

H-E-L-L-O, Hello.

\section{Bill Scranton}

Pennsylvania

1963-1967

Bill Scranton was elected in 1962 as the $38^{\text {th }}$ Governor of Pennsylvania. In 1964, with Arizona Senator Barry Goldwater seen as the frontrunner for the Republican presidential nomination, more moderate Republicans tried to start a "draft Scranton" movement. He announced his candidacy on June $12^{\text {th }}$ just weeks before the party convention selected Goldwater as the nominee. Earlier that year, a group called the "Scranton for President Information Center"' had issued an LP with excerpts of Scranton speeches on one side and, on the other, versions of the Bill Scranton Polka, both with and without words.

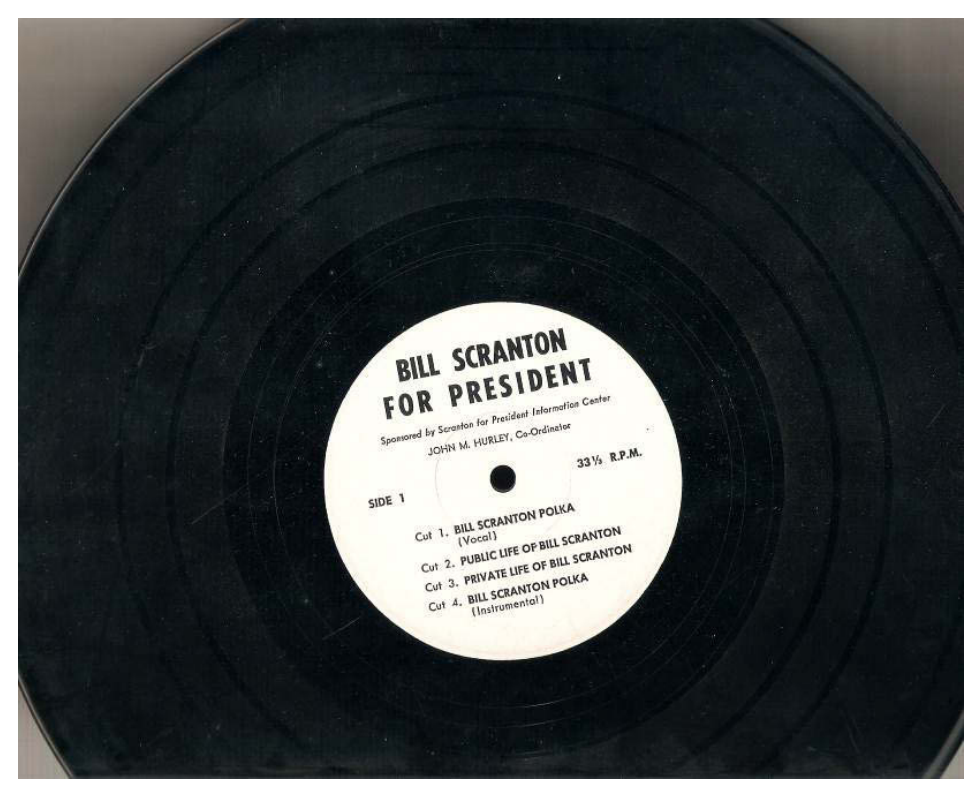

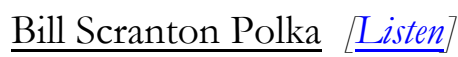

He started in Scranton as a favorite son, A fighting Pennsylvanian

Bill Scranton's a winner, just see what's he's done for the State of Pennsylvania Next job for

Scranton will be Washington, For Bill there is one right house

We're sending him right to the White House, We're all for Scranton from Pennsylvania

Vote Bill Scranton, He will be a fighting president, Vote Bill Scranton, he will be a mighty president

Vote Bill Scranton, vote a strong, aggressive president, Bill Scranton he's our man, vote straight Republican

He'll build a stronger, better USA. 


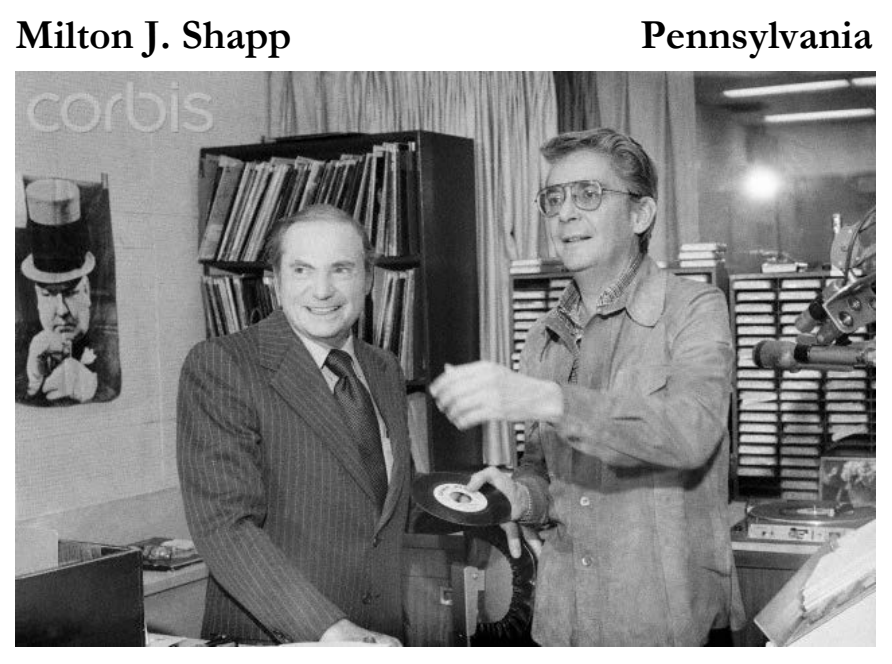

1971-1979

Milton Shapp's two terms as Pennsylvania's first Jewish governor probably left a larger imprint than either his 1976 Presidential campaign or his music. Shapp was, however, a songwriter and composer with at least two unproduced musicals. His Watergate-era song, "The Ballad of Rose Mary (Woods)," was released as a single sung by Sue Levinson. ${ }^{x x i i}$ Listen

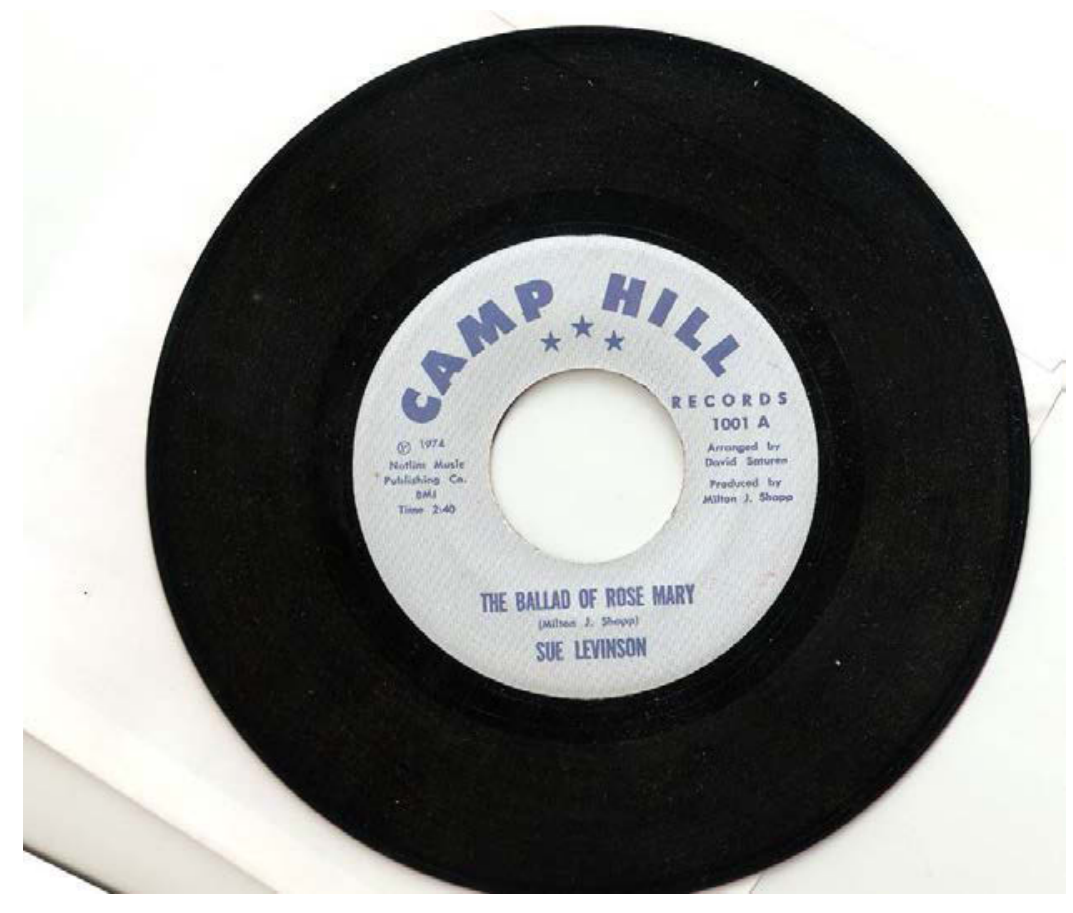




\section{Dan Walker, Illinois 1973-1977}

Dan Walker received national attention when he was elected Governor of Illinois in 1972. Aided by the attention and name recognition he had received from walking across the state, there was speculation that he might someday run for president. His political career ended four years later, however, when he failed to win the Democratic primary for re-election. Later Walker was convicted of bank fraud unrelated to his time in office and served 18 months in prison.

In the middle of Walker's gubernatorial term, Stan Hitchcock, a Nashville-based singer with hit records and nationally syndicated television shows, was approached by the Illinois Democratic Party "about promoting some country music concerts to raise money for their Fund." Hitchcock explained:

Governor Walker was to be the focal point of the concerts, making appearances at each show. I promoted the shows ... in towns across Illinois. I worked closely with Governor Walker, and we became friends. He would invite me to the Gov. Mansion for meals with him and his family. He was an extremely personable gentleman and I really liked him. I was taken with the story of his walk across Illinois and sat down in my hotel room one night and wrote the song. I sang it for him the next day and he got pretty excited about it. David Clevenger, the head of the Democratic Fund, asked me if I would record it if they paid for it. So we did and it came out during the time of the concerts and I would do it at every show. Newsweek Magazine did a story on it about a country singer writing the song about Walker, as did the Chicago Tribune. ${ }^{x x i i i}$

\section{A Winner Walking Home [Listen]}

Illinois sun comes shining through the cornstalks on the road he's walking on

And the bright light shows all the dust on his clothes

He sure could use some rest

But the hopes and dreams of his fellow man

Keep him walking across the Land

It's a long long way to go

His back is tired but not his soul

A Winner Walkin' Home

THE BALLAD OF DAN WALKER

$H e$ 's a winner walking home

Grandmas waving from the front porch,

Farmers coming in from the fields

Lord, they need him so

Stopping at a country store,

Sweat stains on the denim shirt he wore

With a handshake and a look that tells, Here's

a man that means just what he says

Next time that I saw this man,

I reached out and shook his hand

Congratulations -

You've made the name of Governor Dan

Known and trusted all across this land

People from all walks of life bring you their problems and you listen

Yes, there's a winner coming home $e^{\text {xxiv }}$ 
Known my his middle name, Ray Blanton was elected Governor of Tennessee in 1974 after having served in the U.S. House of Representatives from 1967 to 1973. The Democrat chose to not seek a second term in 1978 and was succeeded by Republican Lamar Alexander. Toward the end of his single term, Blanton issued pardons to more than 50 people who had been convicted of murder and other crimes. The outrage and alarm raised by these actions led the Lieutenant Governor and legislature to discover and use a power to have Alexander sworn-in as governor three days earlier than had been scheduled and customary.

The website www.RealClearPolitics.com rates Blanton as one of the "10 most corrupt politicians in U.S history." This list includes four other governors; Huey Long (Louisiana), Edwin Edwards (Louisiana), Spiro Agnew (Maryland) and George Ryan (Illinois).

Within days of Blanton's removal from office, Brian Christie, a Nashville TV weatherman, had written and recorded "Pardon Me Ray," a parody of "Pardon Me Roy." The song, on Sound Factory Records, opens with the line, "Are you the chat that signs the pardons" instead of, "Is this the Chatanooga Choo-choo?" Listen

Bill Clinton

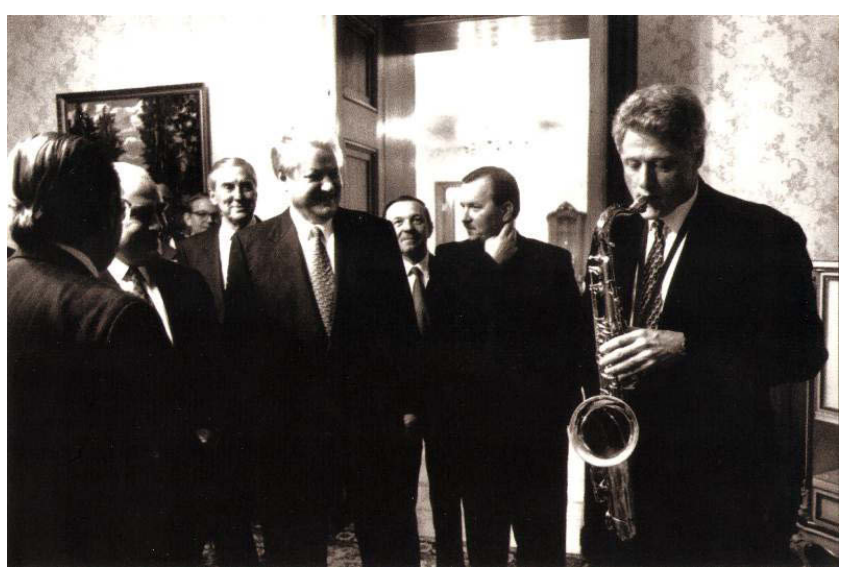

Arkansas
Bill Clinton played tenor saxophone in high school with sufficient skill to gain the first chair in the Arkansas State Band. His playing was not part of his political identity, however, until June of 1992 when his struggling presidential campaign gained a bounce in the polls soon after he performed Heartbreak Hotel on the late-night Arsenio Hall Show on network television. When then-Governor Clinton finished, Hall said, "It's nice to see a Democrat blow something besides the election." [ [ iew]

During his Presidential inauguration seven months later, Clinton played the sax along with Clarence Clemons from Bruce Springsteen's E Street Band. Later, he donated the instrument he had used to the American Jazz Museum in Kansas City, MO.

Clinton's 1994 performance with Vaclav Havel, then President of the Czech Republic, is captured on a CD called Two Presidents Gig.

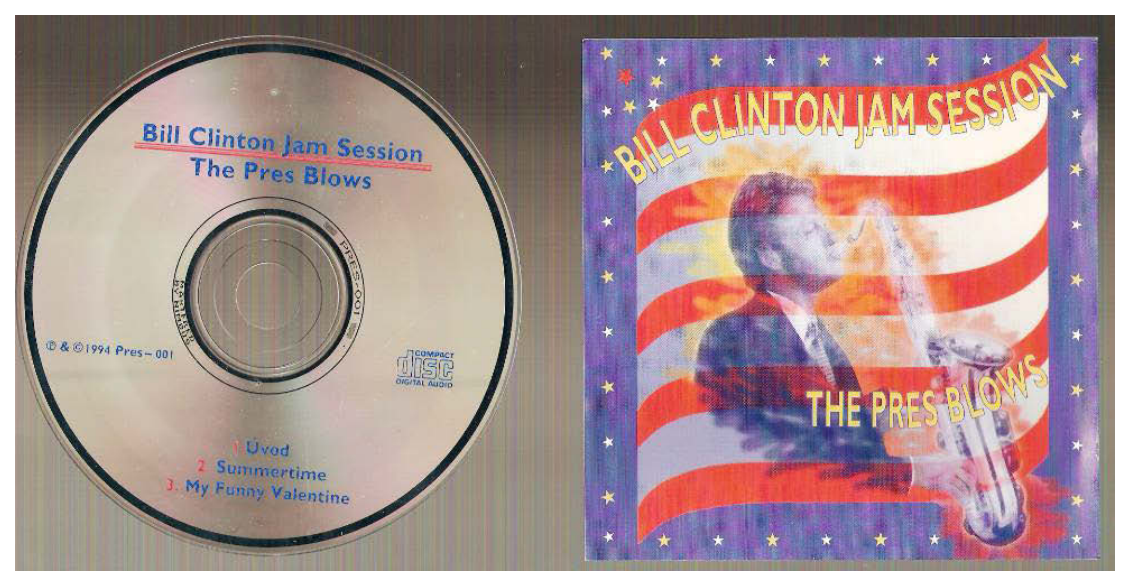

$-18-$ 


\section{Howard Dean}

Vermont

1991-2003

Howard Dean was Vermont's Lieutenant Governor in 1991, when Governor Richard Snelling died in office. Dean was then elected to five two-year terms before declining to run again in 2002. When he stepped down, he was little known outside of Vermont, but in his subsequent campaign for the 2004 Democratic presidential nomination, Dean unexpectedly became the frontrunner. His campaign was derailed on the night in January when not only did he come in third in the Iowa caucuses, but his widely-seen, televised comments to his supporters seemed to be in the form of a scream. Shortly after the campaign, singer-songwriter Aaron Nathans, who had known Dean "before the scream," wrote I Remember Howard Dean. Asked about the song, Nathans responded:

What led me to write it? [My song] "Senator McCain" was always a crowd pleaser, so I went back to the well, so to speak... and I had this personal story about my own interactions with Governor Dean at right about the time he was becoming - nationally known. I was always struck by how different his persona was nationally this passionate progressive - from the more buttoned-down city manager type we knew in Vermont, when I covered him as a wire service reporter in 1996 and 1997. I wrote it in 2004, and didn't play the song for a while after 2006 or 2007, figuring it was out of date. But I revived it recently, and it tells a nice historical story about the Dean campaign that holds up nicely. Everybody remembers Howard Dean... ${ }^{\mathrm{xx}}$

\section{Remember Howard Dean [Listen]}

I remember Howard Dean, Seven years before the scream

Seven years before the meet-ups, In Manhattan cocktail lounges

Seven years before the stand, Before things got out of hand

But I remember Howard Dean, He was cold but he was clean

And he never felt your pain, But he always spoke his brain

You could get him on the phone Just by calling him at home He was almost never mean

I remember Howard Dean

I remember Howard Dean He was always in between He was not a liberal man And be barely spent a cent And his crew was like a cult With each political assault They would take one for the team I remember Howard Dean ...

In the tears of crowds adoring I recalled when he was boring I remember Howard Dean When the fiscal years were lean But he always put away Something for a rainy day He never went away

But things were never quite the same And it all feels like a dream I remember Howard Dean ${ }^{x x y i}$

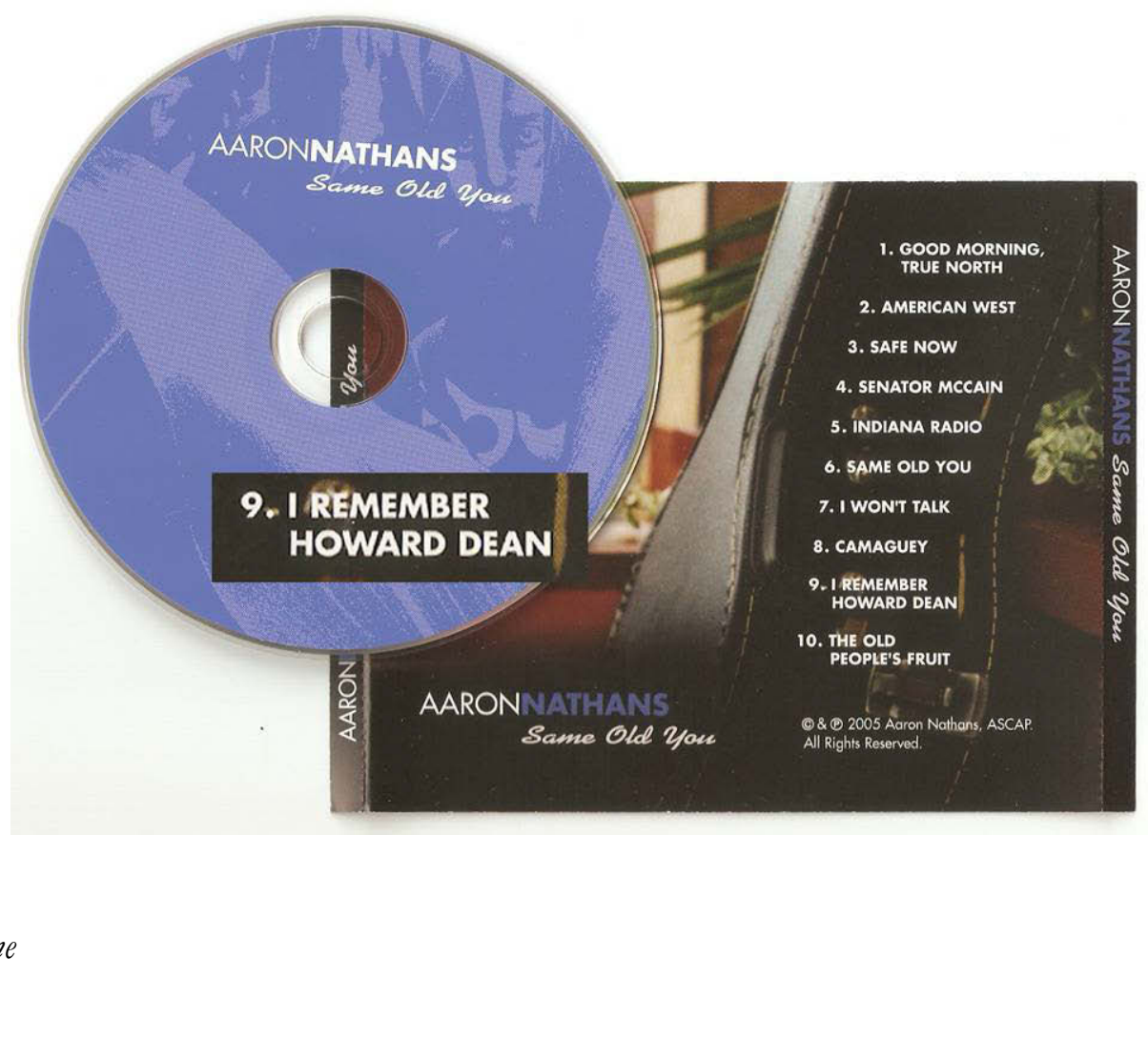


Mike Huckabee

Arkansas

1996-2007

Mike Huckabee served two terms as Governor of Arkansas and then made a strong campaign for the 2008 Republican presidential nomination. He has made his musical hobby part of his public political persona, playing bass with at least two bands - Capitol Offense and The Little Rockers. Recordings of his bass playing can be viewed on YouTube and other locations. [View]

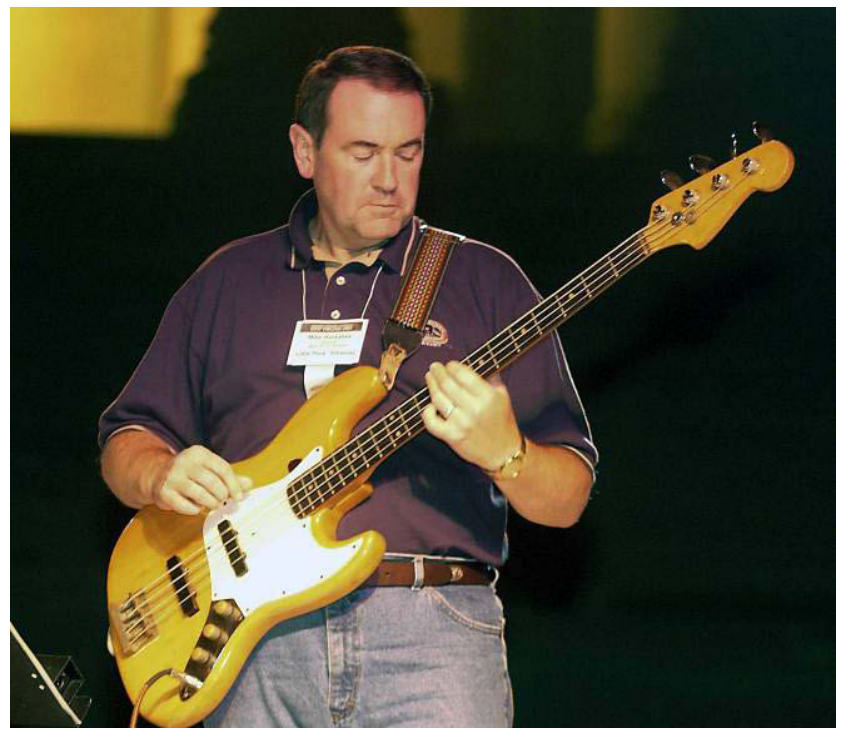




\section{Five Governors}

Donald DiFrancesco
John Farmer
John Bennett
Richard Codey
James McGreevey

New Jersey

$2001-2002$

January 31, 2001 - January 8, 2002

January 8, 2002 - later on January 8, 2002

January 8, 2002 - January 12, 2002

January 12, 2002 - January 15, 2002

January 15, 2002 - November 15, 2004

We Had Five Governors In Eight Days, by singer-songwriter Dave Kleiner, is a humorous portrait of an odd, truly unique, eight-day period in recent New Jersey political history during which five people held the post of governor.

Until 2005, the New Jersey Constitution stipulated that if the governor's post became vacant, it would be filled by the President of the State Senate, but only as long as that person remained in the legislative leadership post. As a result, when Governor Christine Todd Whitman left office early in 2001 to become Administrator of the U.S. Environmental Protection Agency, Senate President Donald DiFrancesco added the post of Acting Governor to his portfolio. The Republican legislator had been chosen to be Senate President when his party gained a majority of the seats in the Senate.

In November 2001 as New Jersey voters chose the Democratic nominee, Jim McGreevey, to be the next Governor, they also elected a new State Senate that would be evenly divided with 20 Democrats and 20 Republicans. Under the Constitution, the new legislature would take office on January 8, 2002 followed on January $15^{\text {th }}$ by the swearing in of the new governor.

This created a brief moment between the end of the previous legislature's term and the start of the new one when New Jersey technically had no Senate President. Constitutionally next in line to be governor was the State Attorney General, and so it was that on January 8, 2002 John Farmer was sworn in as Acting Governor.

Farmer's tenure extended to later in the day when the new State Senate took office. Due to the 20-20 even partisan split, the members agreed to be led by two co-presidents who would take turns holding the post.

The new Republican leader, Senator John Bennett, went first and served as Acting Governor from January $8^{\text {th }}$ to January $12^{\text {th }}$ when his Democratic colleague, Senator Richard Codey, took the Acting Governor reins and held them until January $15^{\text {th }}$ when Jim McGreevey was sworn in as the duly elected Governor of the State of New Jersey.

New Jersey folksinger Dave Kleiner managed to summarize this saga in a little over two minutes with the catchy chorus:

Five Governors in Eight Days [Listen]

We had five governors in eight days, we had five governors in eight days

Let me check my watch, who's the governor today

We had five governors in eight days

It was DiFrancesco, Farmer, Bennett, Codey, McGreevey

DiFrancesco, Farmer, Bennett, Codey, McGreevey

Five governors in eight days.

In 2005, New Jersey voters amended the State Constitution to create the office of Lieutenant Governor and change the line of succession. The holder of the new position is permitted to also be a member of the governor's cabinet, but not to be a legislator. In 2009, Kim Guadagno was elected the state's first Lieutenant Governor. She also serves as Secretary of State. 


\section{Cornelius “Con” Hogan}

Vermont Candidate

2002

Con Hogan was the Secretary of Human Services in Vermont before running as an independent candidate for Governor in 2002, when Howard Dean chose not to seek a sixth two-year term. Hogan won about $10 \%$ of the vote, but lost to Jim Douglas, the Republican nominee. When asked his thoughts about the contest afterwards, Hogan said, "Well, one way to look at it is that I spent 10\% of the aggregate sum spent by all candidates in the race - and I received $10 \%$ of the votes." xxvii

Hogan has also long been the banjo player in the Cold Country Bluegrass Band, a group which recorded an ad for his campaign that was sung at campaign events, but never actually used on the radio. ${ }^{\text {xxiii }}$ [Listen]

\section{Rod Blagojevich Illinois 2003-2009}

Rod Blagojevich served as Governor of Illinois from 2003 until January 29, 2009 when he was impeached by the legislature and removed from office. Subsequently convicted of several charges including having tried to sell the U.S. Senate seat vacated by Barack Obama, Blagojevich has been in federal prison since March 15, 2012.

In the category of kicking someone while they're down, Kelly Brand, a Chicago jazz composer and pianist, wrote and recorded Rodney The Red-Faced Governor. The song also makes reference to three other recent Illinois governors before Blagojevich who went to jail; Otto Kerner (1961-1968), Dan Walker (1973-1977) and George Ryan (1999-2003). Serving between Kerner and Blagojevich with no known legal troubles were Samuel Shapiro (1968-1969), Richard Ogilvie (1969-1973), Jim Thompson (1977-1991) and Jim Edgar (1991-1999). ${ }^{\text {xix }}$

There was Otto Kerner and Dan Walker lying

Our last one now sleeps in a cell, that's George Ryan

But we're so appalled by the skankiest governor of all

Governor Rod Blagojevich had a very funny name... 


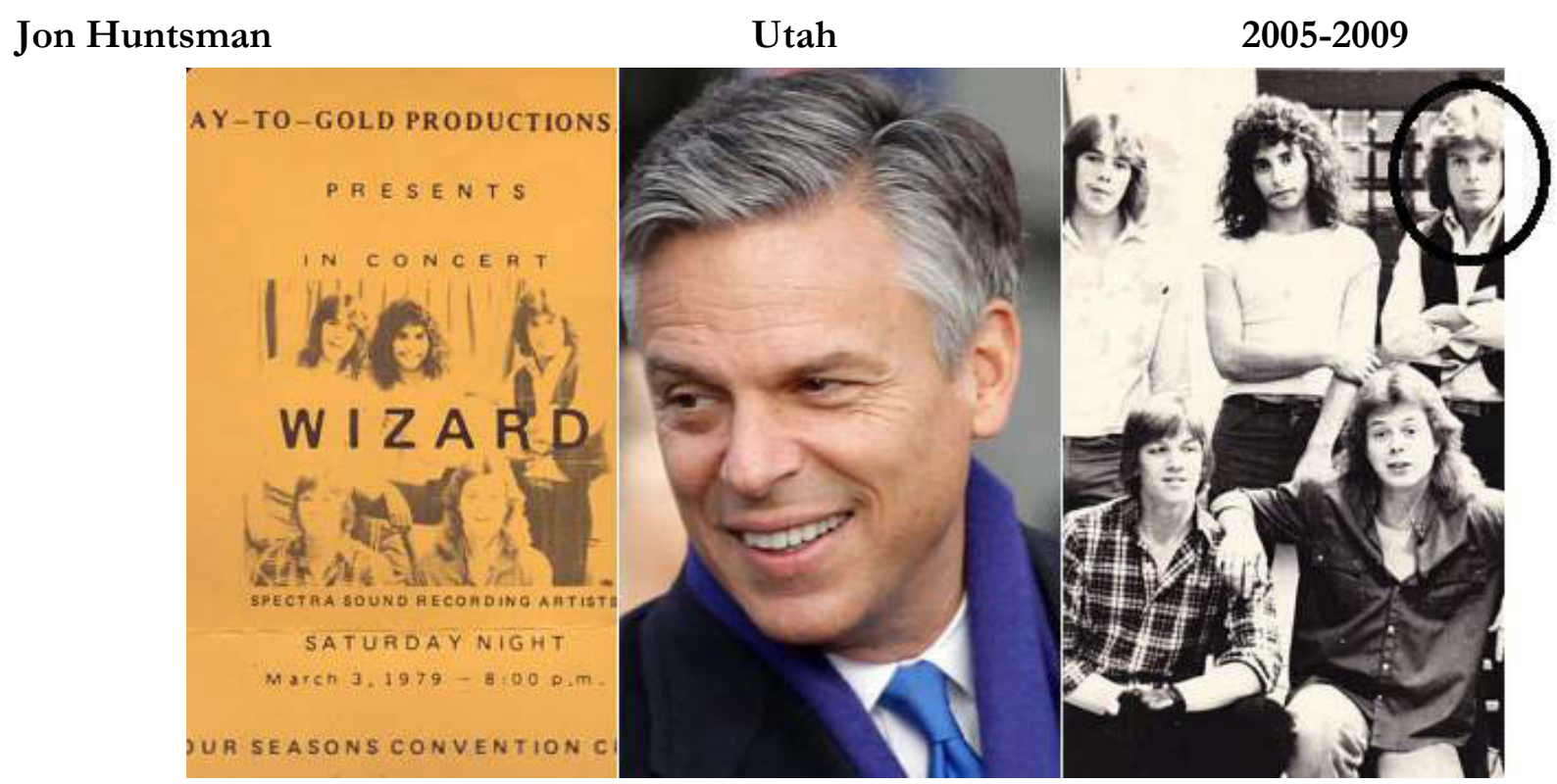

Jon Huntsman was elected Governor of Utah in 2004. Soon after being reelected in 2008, he accepted nomination by President Barack Obama to serve as Ambassador to China. It was only after he stepped down from that post to seek the Republican presidential nomination in 2012 that his early musical career became national news. In his youth, it became known, Huntsman had dropped out of high school to tour with his rock band, Wizard, for which he was the keyboard player.

Kinky Friedman

Texas Candidate

2006

Kinky Friedman, a well-known and often humorous country singer and mystery writer, ran for Governor of Texas in 2006. He received nationwide publicity, but only $13 \%$ of the vote. His persona and campaign is described by Burgin Mathews in the introduction to Singing Governors, Fiddling Senators:

"Surely one of the most colorful candidates in recent memory for any high-profile public office was iconoclastic country singer, detective novelist, cigar-chomping humorist and, in 2006, would-be Texas governor, Kinky Friedman. Friedman had first gained cult-culture status in the 1970s as frontman to the Texas Jewboys, a band that dished out both social commentary and bawdy humor in such songs as Get Your Biscuits in the Oven and Your Buns in Bed, They Ain't Making Jews

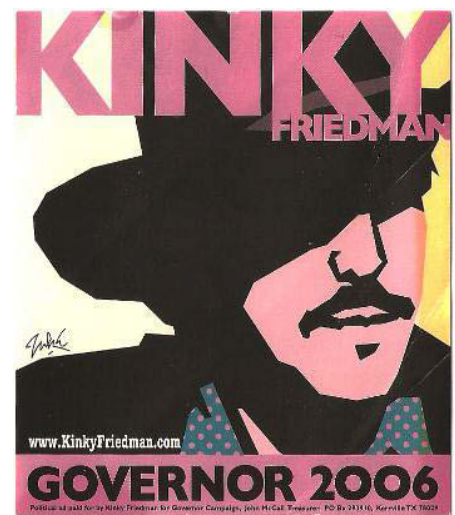
Like Jesus Anymore, and "Asshole from El Paso.". In the eighties Friedman emerged as an author, churning out, among other writings, a series of novels that usually starred a loud-mouthed TexasJewish detective, relocated to the Big Apple and named, well, Kinky Friedman. As an author he proved prolific, sometimes releasing two or three books in a single year. And then, in 2006, Kinky turned to politics: calling for the "dewussification" of Texas, he launched a campaign for that state's governorship, touting slogans like "How Hard Can it Be?" and "Why the Hell Not?"

Throughout the race, Friedman sold himself as the anti-politician, a stranger to both the political establishment and to political correctness, and he appeared at rallies and debates stabbing his cigar in the air and spouting from beneath a black cowboy hat characteristic one-liners-sometimes irrelevant, often crass, and now and again downright brilliant—which left his more traditional opponents bristling. Kinky lost, by a landslide. ${ }^{\mathrm{xxx}}$ 


\section{Martin O'Malley}

[View1] [View2] and Listen]

\section{7-Present}

Martin O'Malley, the current Governor of Maryland elected in 2006 and reelected in 2010, leads a Celtic folkrock band called O'Malley's March. The seven-piece band has released four CDs with O'Malley playing guitar and whistle and serving as the lead singer. While the band was more active when O'Malley was a Baltimore Councilman and then Mayor, it continues to perform at venues including the Ram's Head Inn in Annapolis as well as occasional governmental functions.

In 2012, when Irish Prime Minister Edna Kenny visited the White House, O’Malley was the only governor invited to sing at an East Room celebration. Though the band is very good President Obama in his subsequent remarks was reported to have joked:

They say the curse of the Irish, as the Governor knows, is not that they don't know the words to a song. It's that they know them all. ${ }^{\text {xxi }}$

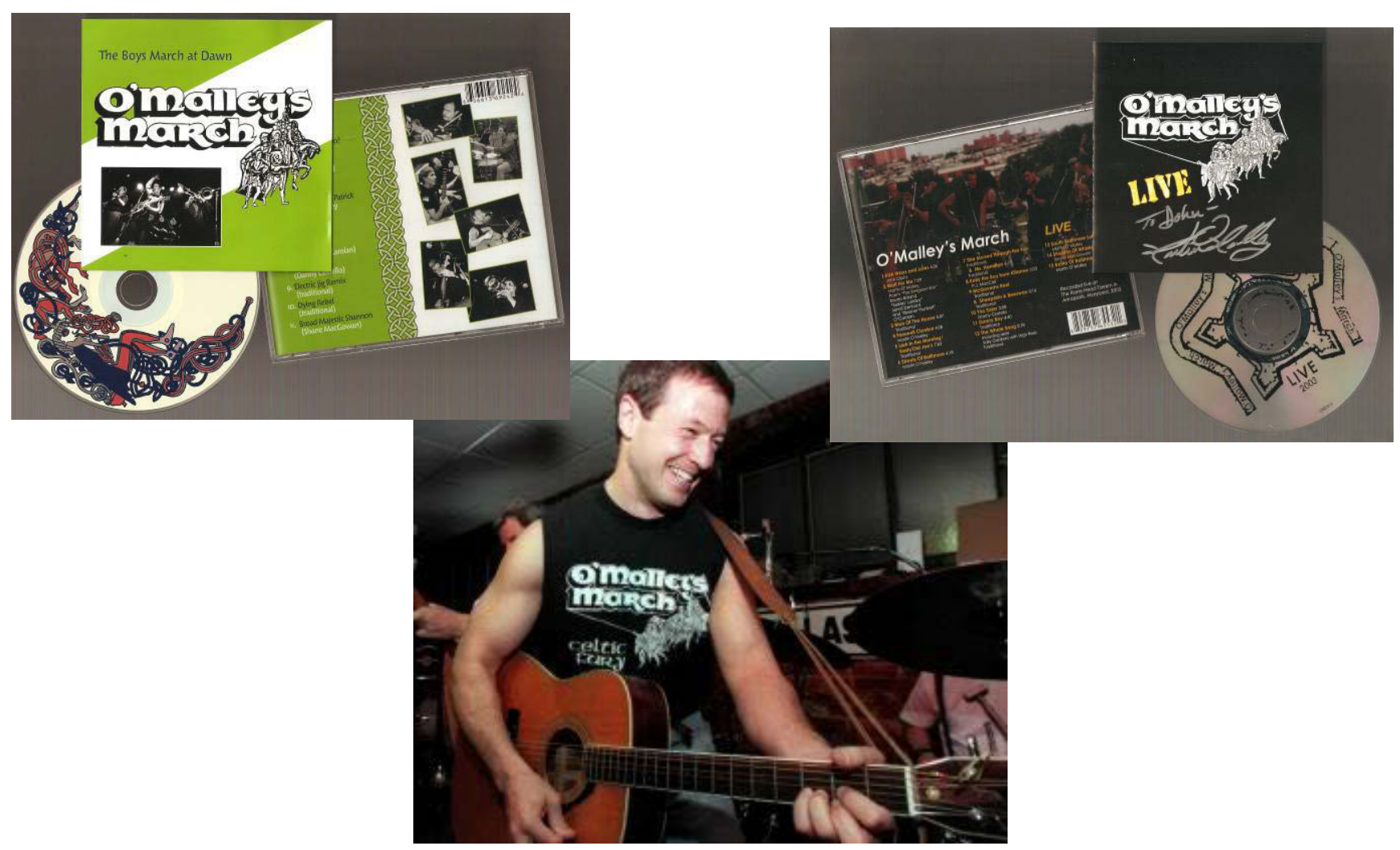

\section{Scott Walker \\ Wisconsin \\ 2011 - Present}

Disagreeing with many actions taken during Governor Scott Walker's first year in office, mostly Democratic opponents obtained the necessary signatures to require a recall election only 18 months into his term. The issue that most sparked the reaction was Walker's successful effort to significantly reduce the power of public worker unions. In the recall vote on June 5, 2012, Walker triumphed with a slightly larger percentage of the vote than he had received when first elected in November of 2010.

These events led Art Paul Schlosser, a street musician in Madison, Wisconsin, to release an album of 19 original songs with titles including Scott Walker Loves You, Scott Walker Blues, Recall Walker" and the title song, If I Was Governor. $x^{x x x i i}$ 


\title{
Excerpts from
}

\section{Singing Governors, Fiddling Senators and other country-music politicians}

\author{
A guide by Burgin Mathews
}

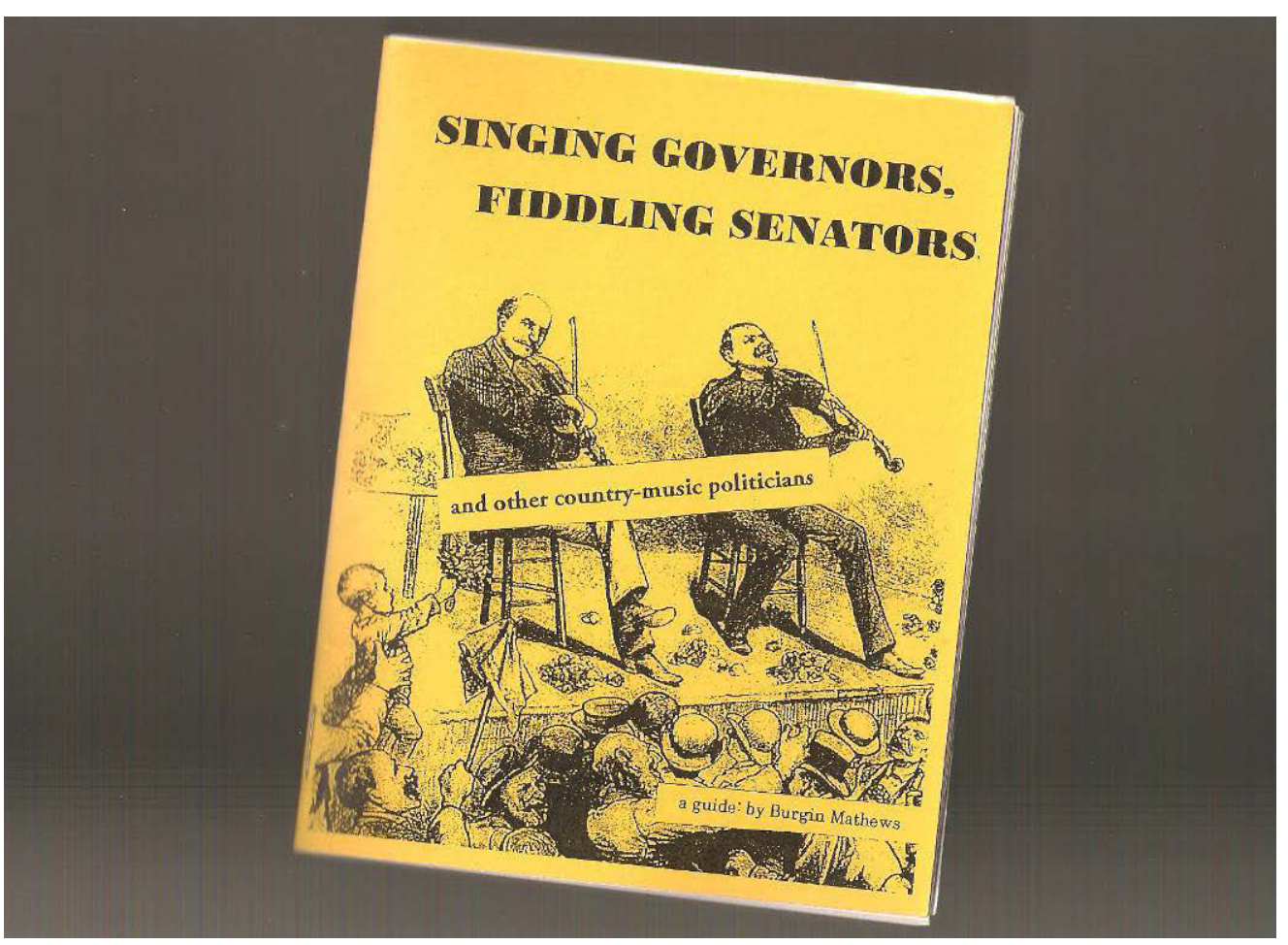

Singing Governors, Fiddling Senators and Other Country-Music Politicians is a booklet written by Burgin Mathews, a folklorist, author and teacher from Birmingham, Alabama. It was published by Lady Muleskinner Press in Birmingham in 2008.

With permission of the author, the Center on the American Governor has reproduced the three chapters devoted to governors. The complete booklet provides similarly informative, charming and unique perspectives on many other politicians and would-be politicians who were also, in some meaningful and more than passing way, musicians. This includes Tex Ritter, DaCosta Woltz, Senator Al Gore, Senior, Lulu Belle Wiseman, and Senator Robert Byrd.

\section{BOB AND ALF TAYLOR}

Probably the most storied political fiddlers of all time were Tennessee brothers Robert Love (Bob) and Alfred Alexander (Alf) Taylor, who ran against each other on opposite tickets in the governor's race of 1886. The brothers traveled the state, debating by day, singing and fiddling by night, and often sharing a hotel bed before moving on to their next engagement. Tennesseans dubbed the race the "War of the Roses," as Bob's supporters took to wearing white roses and Alf's to red. Ultimately, voters' minds were swayed more by politics than fiddle-prowess: Bob, the weaker fiddler but a Democrat in an era of Southern Democrats, won the election. Then, of course, there was Bob's flamboyant personality. In the fiddling arena, Bob made up for any technical shortcomings by his 
showmanship and entertaining antics: as one contemporary explained, "It wasn't that Bob was a wonderful fiddler, but the way he looked when he was playing. Bob's whole person fiddled. He could fiddle from the top of his head to the bottom of his toes." Just the sight of Bob shaking, followed by a comical ballad or opera impersonation, would send a crowded hotel lobby into hysterics. Immensely popular, the Republican Taylor served three terms as governor between 1886 and 1899, and after a premature "retirement" from politics was elected to the U.S. Senate in 1907.

Both brothers were defeated by Republican Ben Hooper in the 1910 governor's race. Alf's political career began with his entry into the state legislature in 1885; from 1889 to 1895 he served in Congress, and in 1920 - more than three decades after his original run against his brother (and seven governors later) - he won the Tennessee governorship. Alf would, incidentally, make the only records pressed by either brother, a couple of tunes with the Old Limber Quartette, a group named for Alfs hunting dog (dogs were also part of the Taylors' populist identification with the people"We played the fiddle, were fond of dogs, and loved our fellow man," Alf later offered in explanation of the brothers' long popularity).

The brothers earned further fame on the lecture circuit, where, again, they combined fiddling, politics, and good-humored antics. Bob first took to the lecture circuit between his second and third terms as governor, finding himself broke despite the success of his political career. His best-known speech, which he delivered to audiences across the U.S. and with which he managed to pull himself out of debt, was a lengthy celebration of the musical impulse, titled "The Fiddle and the Bow." ("Long live the common people of America!" Bob would exclaim, championing the popular association between populism and down home music. "Long live the Fiddle and the Bow, the symbols of their mirth and merriment!") Later, the brothers toured together, offering a double-bill titled "Yankee Doodle and Dixie." Republican Alf spoke first of a post-Reconstruction, happily united United States, in which "the music of 'Yankee Doodle' and the music of 'Dixie"' could mingle in harmony, the animosities of yesteryear's Civil War finally dead. Robert spoke next, opening with a nod toward unification, but proclaiming gladly that "Mason and Dixon's line is still there," and rousing the crowd with spoken and sung tributes to the Southland.

Bob Taylor died in 1912, in the middle of his Senate term; he never lived to see his younger brother take his old seat in the governor's office. Alf lost his reelection bid for that seat in 1922 . He died nine years later.

\section{"PAPPY" LEE O'DANIEL}

Of all musical politicians, W. Lee "Pass the biscuits, Pappy" O'Daniel-flour magnate, two-term Texas governor, and U.S. senator-surely had the greatest impact on the history of country music, despite the fact that he himself neither played nor sang. The 2000 Coen Brothers movie O Brother, Where Art Thou borrowed O'Daniel's name and bits of his mythology for its Charles Durning character, transplanting him from Texas to Mississippi; the music associated with the real Pappy Lee O'Daniel, however, was pure Texas, an amalgam of hillbilly fiddling, hot jazz, Texas-Czech and German polka, Mexican border music, and blues.

It was called "western swing."

O'Daniel came to Fort Worth in 1925 (he was born in Malta, Ohio, and had lived most recently in New Orleans); with over a decade already under his belt as a flour salesman, he became sales manager of Fort Worth's Burrus Flour Mill and Elevator Company, producers of Light Crust Flour. The mill sponsored a radio program and O'Daniel became its announcer, hiring a band he dubbed the Light Crust Doughboys (formerly the Aladdin Laddies; their previous gig had been on a show sponsored by 
the Aladdin Lamp Company) to help promote his product. O'Daniel fired the band after a few shows, expressing disdain for what he considered "hillbilly music," but he hired the boys back quickly when he discovered the enormous following they (and, by association, his company's flour) had already developed. O'Daniel became the group's announcer and manager, expanding its radio performances throughout the Southwest and even writing poems which the band set to music - a few of which, like "Put Me in Your Pocket" and "Beautiful Texas," became standards of the genre and, ultimately, of the region. Another Pappy Lee composition, 1933's "On to Victory Mr. Roosevelt," prophesied FDR's triumph over the Depression economy; early in his own political rise, O'Daniel would associate himself often with the Roosevelt name, only in his later years to become a vehement critic of that president.

The original band members-Herman Arnspiger on guitar, Milton Brown on vocals, and Bob Wills on fiddle-each would prove enormously influential in the development of western swing. Brown and Wills had both left the Doughboys by 1933, due to disagreements with the dictatorial O'Daniel, but the bands they formed after their departures (Brown's Musical Brownies and, in particular, Wills' Texas Playboys) became the two biggest bands in this new music. The Light Crust Doughboys continued to bring in hot talent, and varying lineups of the band performed all the way to the close of the $20^{\text {th }}$ century. After leaving Burrus Mill in 1935, O'Daniel founded his own W. Lee O'Daniel Flour Company, makers of Hillbilly Flour and sponsors of the Hillbilly Boys, another western swing outfit, for which O'Daniel would recruit local players, including his own musical children. In 1938 this band became the main attraction in O'Daniel's successful campaign for the Texas governorship, a campaign centered squarely around flour, Christian morality, and fiddle music. The Hillbilly Boys came with O'Daniel to Austin, the state capital, where he found them each jobs working for the state (in earlier years, the Doughboys had similarly worked day jobs packing flour).

O'Daniel played a fundamental role in popularizing the unique Texas sound and in jump-starting a handful of legendary musical careers; his personality loomed large, for years, over the Texas cultural landscape. As a band manager, though, he was uniformly considered unfair, condescending, crassly manipulative and unreasonably demanding. His political reputation was little better: despite his reelection in 1940, he proved an inept governor, whose policies were ineffectual and whose campaign promises all came to nothing. In 1941, O’Daniel bested opponent Lyndon Johnson for a seat in the U.S. Senate (the only campaign Johnson ever lost for any political office), but by his retirement in 1948, the polls charted his public support at less than ten percent. If his radio persona and his association in the public mind with red-hot dance music had for much of his career been able to overshadow his political and personal shortcomings, the public had finally had all they could take. A longtime anti-labor crusader, he blamed his profound unpopularity on the Communists.

In the 1950s O'Daniel reemerged from his Texas ranch for two very unsuccessful gubernatorial bids, during which he railed again against Communism and now desegregation but got himself nowhere.

The fiddle-and-flour days, for Pappy Lee, were over.

\section{GOVERNOR JIMMIE DAVIS}

The granddaddy of all country music politicians was two-term Louisiana governor, singing cowboy star, and (possible) "You Are My Sunshine" composer Jimmie Davis. The son of sharecroppers, Davis worked his way through college, in part by playing his guitar on street corners; he earned a master's degree from LSU and in 1927 began teaching social studies at a women's college in Shreveport, doubling as a performer on local radio station KWKH (later home of the celebrated “Louisiana Hayride”). Davis' early style, apparent on 68 songs cut for Victor Records between 1929 
and 1933, was essentially an imitation of the immensely popular singer Jimmie Rodgers, and featured frequent yodeling and (on songs like "Red Nightgown Blues," "High Behind Blues," and "High Geared Mama") risqué double-entendre. When Davis moved to Decca Records in 1934, he gained a broader audience as a smooth country crooner, and in the years that followed he had major hits with "Nobody's Darling But Mine," "It Makes No Difference Now," and "You Are My Sunshine." Rodgers claimed authorship to "Sunshine," in truth a questionable assertion; at any rate, he held the copyright and without question brought the song to the national consciousness, molding it into its recognizable form. In later years, he would lead sing-alongs of the song at his campaign rallies, and the tune became so heavily associated with Davis' Louisiana (without actually making any specific reference to the state) that it became an official state song.

Davis' political career began with a stint in Shreveport's Criminal Court office, followed by gigs as police chief and Commissioner of Public Safety in that city; in 1942 he became Public Service Commissioner, and supporters were soon urging him to run for governor in the "44 election. ("I turned down a fortune," Davis later said of his decision to run: he was making more money as a singer and film star than he ever could as governor, and he knew it.) Music was central to Davis' campaign, which boasted a platform of "Peace and Harmony": at his campaign stops, other candidates on his ticket would speak first and Davis would follow, with fifteen minutes of speech and fifteen minutes of song. Opponents protested, predictably, that his campaign was heavy on music and light on substance, and they pointed to the questionable morality of his early records, but the public didn't seem to mind. One candidate played a record of "Red Nightgown Blues" to a park full of prospective voters, hoping to expose his opponent's blatant immorality; the trick backfired (so, at least, the story goes) as couples all over the park began dancing.

Though Davis' first term was very productive, the new governor still found time, amidst all his political duties, for music: he was known, for example, to serenade members of the House of Representatives to lighten the mood when things became tense on the floor. Davis still managed to record on the weekends, and during his first term scored five top-five singles, including the numberone "There's a New Moon Over My Shoulder." Davis had already starred in three B-movie Westerns before winning the governor's seat, and he drew some flak in 1947 when he left his office for twelve days in Hollywood to star as himself in the musical movie-biography Lonisiana. Davis returned fulltime to performing after his first term (the state constitution then outlawed consecutive gubernatorial terms), now devoting himself primarily to gospel material. In 1960 he returned to the governor's office for another four years. Davis married Anna Carter Gordon, a singer with the country gospel group the Chuck Wagon Gang, in 1967, and for years the couple were the sweethearts of the country gospel world. His political sunshine finally set, Davis fared poorly in a final bid for the governor's office in 1971. The forced political retirement allowed him to spend the rest of his days enjoying his other career, though, performing gospel music and frequent reprises of "You Are My Sunshine." He died in 2000, at the age of 101. 


\section{SELECTED BIBLIOGRAPHY}

\section{RELATED RELEVANT RECORDINGS}

Oscar Brand; Presidential Campaign Songs, 1789-1996; Smithsonian Folkways; 1999.

Peter Janovsky; Winners and Losers: Campaign Songs from the Critical Elections in American History, Volumes I and 2; Smithsonian Folkways Records.

\section{BOOKS and ARTICLES}

Michael Anthony; "Whatever happened to the campaign song?"; Minneapolis Post; November 1, 2012.

Paul Deresco Ausburg; Bob and Alf Taylor: Their Lives and Lectures. Morristown, TN: Morristown Book Company, 1925.

Joyce Cauthen; With Fiddle and Well-Rosined Bow: Old-Time Fiddling in Alabama;

University of Alabama Press; Tuscaloosa, AL; 1989.

M. Smith Gibbs; Joe Hill: Labor Martyr; Grosset \& Dunlap; 1969

Chris Goertzen; “George Cecil McLeod, Mississippi’s Fiddling Senator, and the Modern History of American Fiddling;" American Music; Fall 2004.

Handbook of Texas Online: Articles on "Light Crust Doughboys," "O’Daniel, Wilbert Lee," and "W. Lee O’Daniel and His Hillbilly Boys," www.tsha.utexas.edu/handbook/online/articles.

Dik de Heer, Leiden, the Netherlands; info on Jay Chevalier (dik.de.heer@hetnet.nl).

Bill C. Malone; Country Music USA; Austin: University of Texas Press; 1968.

Bill C. Malone; Don't Get Above Your Raisin': Country Music and the Southern Working Class; University of Illinois Press; Urbana, IL:2002.

Peter Mikelbank; "Places in the Sun: The Many Splendored Careers of Jimmie Davis." The Journal of Country Music, Vol. 10 No. 3.

William Miles; Songs, Odes, Glees, and Ballads: A Bibliography of American Presidential Campaign Songsters; Greenwood Press; 1994.

Bill Wagner; “Two Men, Two Fiddles, and A War of the Roses;” Bluegrass Unlimited Magazine; Warrenton, VA; August, 2010.

Chris Willman; Rednecks and Bluenecks: The Politicians of Country Music; The New Press, New York, NY; 2005. 


\section{ACKNOWLEDGEMENTS}

Thanks to:

Colleague:

Andy Murphy, Rutgers Political Science Professor and Director of the Walt Whitman Center for the Culture and Politics of Democracy for helping to instigate and co-sponsor this project

Fellow Radio DJs:

Taylor Caffery, host of Hootenanny Power on WRKF radio in Baton Rouge, LA, for suggesting the Jay Chevalier song about Louisiana Governor Earl Long;

Art Menius, host of From The Roots on WMMT in Whitesburg, KY, for suggestions of songs from The Carolina Nighthawks about New York Governor Al Smith and from Champion Jack Dupree addressed to a Governor of Georgia;

Musicians:

Gary Kanter of Washington State for alerting me to Phil Ochs' Joe Hill reference to Utah Governor William Spry;

David and Ken Kolodner of Baltimore, MD. for suggesting inclusion of Sam Houston;

Henry Koretsky of Harrisburg, PA for suggesting "Tell It to the Guv'nor," an instrumental by Bela Fleck \& the Flecktones and the live version of Warren Zevon's "Mohammed's Radio," from Stand in the Fire, has recast lyrics that reference Jerry Brown's romance to Linda Ronstadt, though I couldn't find a good way to include either in the text;

Writers:

Matthew Kassel of New York City for his insight on The Fables of Faubus

Burgin Mathews of Birmingham, AL for writing Singing Governors, Fiddling Senators and his generosity in allowing the chapters on governors to be reprinted here. 


\section{END NOTES}

'Robert L. Taylor from "The Fiddle and the Bow: A Lecture" quoted by Burgin Mathews; Singing Governors, Fiddling Senators and Other Country-Music Politicians; Lady Muleskinner Press; Birmingham, Alabama; 2008.

ii The MTA Song; written by Jacqueline Steiner and Bess Lomax Hawes in 1949; Recorded by The Kingston Trio in 1959 and released on The Kingston Trio At Large (Capitol), the song is available on many collections. Indicative of its enduring fame is the song's inclusion on albums of Irish Party Songs and World Scout Jamboree Songs.

iii See, for example, Dear Mrs. Roosevelt written by Woody Guthrie immediately after FDR's death.

iv Available versions of TheWhite House Blues range from a 1930 recording by Charlie Poole and the North Carolina Ramblers (County Records) to a 2013 album by The Tuttles with A.J. Lee from California (Endless Ocean; http://thetuttleswithajlee.com/home.cfm). The added verse about Jimmy Carter appears on an album by Vassar Clements (The Bluegrass Session; Flying Fish; 1977) and was written by band member Bob Hoban.

"Quoted by Stephen Rodrick in "Running Weld: The Quixotic Candidacy of the partying partrician who wants to be governor, again”; New York Magazine; December 29, 2005.

vi Philip Gibbs; The Petroleum Age; ( http://www.reverbnation.com/philipgibbs); 2011. Quote from July 2013 correspondence with John Weingart.

vii Phil Ochs; Joe Hill, originally recorded on the LP Tape From California; Elektra Records; 1978.

viii Donald Thompson quoted by Marshall Wyatt, album notes, Music From the Lost Provinces, 1927-1931; Old Hat Records; Raleigh, NC;1997.

ix Lead Belly; Governor Pat Neff; Gwine Dig A Hole To Put The Devil In - Library of Congress 1940 Recording, Volume Two by Alan Lomax; Rounder Records; 1991 Re-Issue; Cambridge, Mass.

${ }^{x}$ Kip Lornell, Office of Folklife Programs, Smithsonian Institution, album notes written to accompany the 1991 rerelease by $\mathrm{CD}$ cited above.

xi "Every Man A King" and "Kingfish" were both recorded by Randy Newman (Good Old Boys; Warner Reprise; 1974). "Kingfish" was also recorded by Levon Helm (Electric Dirt; Vanguard, 2009).

${ }^{x i i}$ Kip Lornell, Office of Folklife Programs, Smithsonian Institution; Album notes accompanying Midnight Special Library of Congress 1940 Recording by Alan Lomax; Rounder Records; Cambridge, Mass; 1991 re-issue.

xiii The only other known entry for "The Music of Lieutenant Governors" would be the career of Mike Curb who was a musician and head of his own company, Curb Records, as well as Lieutenant Governor of California from 1979 to 1983.

xiv Lead Belly; "Governor O.K. Allen;" Midnight Special; Library of Congress 1940 Recording by Alan Lomax; Rounder Records; Cambridge, Mass; 1991 re-issue.

${ }^{x v}$ Reviewing Lead Belly: A Life in Pictures (Tiny Robinson and John Reynolds; Steidl, Gottingen, 2008), musician, folklorist and photographer John Cohen provides succinct insight into Lead Belly's post prison career:,

A careful reading of the photographs reveals the dilemma of Lead Belly's life: the shaping of his public image and his desire for dignity and respectability. Lomax and his counterparts felt they could only succeed in promoting Lead Belly by exploiting his status as an ex-convict. He was their discovery, their cash cow, and -31 - 
they presented him in prison strips and chains, in overalls with bare feet, singing and playing his guitar ion a pile of hay, prompting Life Magazine's 1937 caption "bad nigger makes good minstrel." A brief Lomaxinduced media frenzy in 1932 sensationalized Lead Bellly as a murderer/musician. This characterization plagued Lead Belly his entire life.

xvi xvi Jay Chevalier, "Ballad of Earl K. Long," 45 rpm single; Recco Records; Baton Rouge, LA; 1960. The song is included on a reissue CD called Jay Chevalier \& the Louisiana Long Shots; Rocking Country Sides; Hydra BCK 27123; Germany; 2004. Information about Jay Chevalier comes from notes for that album written by Dieter Moll with thanks to Tony Wilkinson.

xvii Music from O'Daniel's bands is available on a number of CDs reissuing the original 78 recordings including Western Swing Chronicles, Vol.4 - W. Lee O'Daniel; Origin Jazz Library; 2005.

xviii "I'm Going To Write To The Governor of Georgia;" Champion Jack Dupree; Classic Protest Songs; Smithsonian Folkways Records re-issue; 2009.

xix "We're Madly for Adlai"; written by Stu Watson; recorded more recently by Left Field. The Stevenson Papers housed at Princeton University includes sheet music and/or recordings of this song as well as "We Want Adlai: He Knows the Score" (1952), "The Man With the Hole in his Shoe" (1956), "Believe in Stevenson" (1956), and "You Gotta Gotta Win This Time" (1956). (http://www.princeton.edu/ mudd/exhibits/stevenson/madly.html)

${ }^{x x}$ Intermountain Folk Music Council; Rocky Mountain Collection; 115 South Main Street, Salt Lake City, Utah; 1962 (from the collection of the Stanford University Libraries, Stanford, California). The 38-page collection, which includes no songs pertaining to electoral politics other than "Governor Faubus," opens as follows:

The Intermountain Folk Music Council has found a wealth of uncollected music in the West. We are presenting this collection in order to extend to other singers some of our findings with the hope that these very beautiful and singable melodies will become more widespread. This book has been designed with guitar players in mind; We think that you will find some refreshing new songs to add to your repertoire. The original purpose in founding the Intermountain Folk Music Council was to develop an interest in collecting the songs and lore that abounds in our section of the country. These are some of the songs that have been found. Some are indigenous, some are not; We pass them on to you in hopes that you will put them to good use.

The booklet notes that the author of the lyrics is anonymous and introduces the song as follows:

Here is a song which expresses the feelings of many people during the Little Rock episode a while back (To the tune of "The Jersey Butcher.")

xxi Matthew Kassel is a staff writer at The New York Observer. His work has been published by The Wall Street Journal, The Paris Review Daily, The Village Voice, NPR, Capital New York, and The Forward, among other places. His paragraph on The Fables of Faubus was written by request for this paper.

Charles Minghus; "Fables of Faubus, on the album Revenge! The Legendary Paris Concert!.I

xxii Sue Levinson, "The Ballad of Rose Mary (Woods)"; written by Pennsylvania Governor Milton Shapp; 45 rpm single; Camp Hill Record; 1974.

xxiii Email correspondence with John Weingart; July 2013. 
xxiv Stan Hitchcock; A Winner Walkin' Home-Ballad of Dan Walker; 45 rpm single; Aladdin Records; 1974 (http://www.hitchcockcountry.com/).

${ }^{\mathrm{xxv}}$ Aaron Nathans correspondence with John Weingart.

xxvi Aaron Nathans; "I Remember Howard Dean"; Same Old You; 2005 (http://www.aaronnathans.com/).

xxvii Communication from Bill Waldman; July 23, 2013;

xxviii Cold Country Bluegrass Band (http://www.conhogan.com/bluegrass-history.shtml)

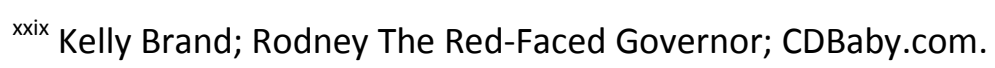

${ }^{\mathrm{x} x \mathrm{x}}$ Burgin Mathews; Singing Governors, Fiddling Senators and other Country-Music Politicians; Lady Muleskinner Press; Birmingham, AL; 2008; pages 1-2.

xxxi Jon Wagner; "O’Malley's March plays set at White House;" Washington Post; March 20, 2102.

xxxii Art Paul Schlosser; If I Was Governor; CDBaby.com. 